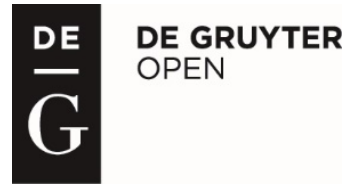

LEGE ARTIS

\title{
'HAUNTED BY AMBIGUITIES' REVISITED: IN SEARCH OF A METAMETHOD FOR LITERARY TEXT DISAMBIGUATION
}

\section{Olga P. Vorobyova}

Vorobyova, O.P. 'Haunted by ambiguities' revisited: in search of a metamethod for literary text disambiguation // Lege artis. Language yesterday, today, tomorrow. The Journal of University of SS Cyril and Methodius in Trnava. Warsaw: De Gruyter Open, 2017, vol. II(1), June 2017. p. 428-496. DOI: 10.1515/lart-2017-0011

\begin{abstract}
This paper addresses the issue of ambiguity in literary discourse, viewed through its multiple verbal and narrative manifestations in Virginia Woolf's short fiction. The research is aimed to combine traditional and most recent techniques of semantic, conceptual, narrative, semiotic, and configurational analyses as constituents of a metamethod of literary text disambiguation, which highlights some hidden features of the writer's linguistic personality.
\end{abstract}

Key words: ambiguity, conceptual analysis, disambiguation, literary discourse, metamethod, short fiction, technique of analysis, Virginia Woolf.

Ambiguity is more than a style [...]. It is the epistemological principle of Modernism. Emotions superimpose themselves in the minds of poets and succeed each other in the hearts of readers without predictability, logic or coherence (Everdell 1997)

It is not ambiguity itself [...] that is artistically pleasing [...]. It is rather the capacity of multiple experiences, even though we are conscious of only one at any given moment, that a stimulus can provide

(Zeki 2006)

\section{Introduction}

Fifteen years ago, in April, 2002, I made a presentation on the ambiguity of narrative viewpoints in Virginia Woolf's A haunted house (Vorobyova 2002) at the IALS (International Association of Literary Semantics) conference in Birmingham. Since that time on, as the title of my abstract goes, I have been truly haunted by ambiguities 
that permeate Woolf's short fiction, each time revealing new and new facets "of multiple experiences" (Zeki 2006: 264) they provide. This paper is the result of my strenuous effort to generalise upon such experiences (Воробьёва 2004; Vorobyova 2002a; 2003) by suggesting what Scholes (1982: 87) once called a metamethod, here of cognitive poetic analysis, adapting it for the purpose of disambiguating literary discourse.

Ambiguity as an artistic phenomenon has never stopped to interest either linguists (Gibbon 2010; Rimmon 1974 et al.) or literary scholars (Ambiguous discourse 1996; Empson 2001; Shaffer 2010 et al.), attracting of late the attention of cognitive and neuroscientists (Beauty and brain 1988; De Mey 2006; Zeki 2006). Quite a few times ambiguity brought together international researchers as an overarching topic for scholarly discussion as, for instance, in Cracow in 2008 (Ambiguity and the search for meaning 2010). Alongside searching for mechanisms behind ambiguity of and in literary discourse, scholars, and readers too, face the problem of disambiguation (Jodłowich 2010 et al.) that constitutes a separate theoretical and empirical issue.

Identification of ambiguities in literary text as well as its disambiguation envisage possessing analytical skills as part of the readers' innate and / or acquired strategies of interpretation. Such strategies shape individual cognitive styles in their interaction with stereotypical and / or idiosyncratic emotional response, jointly forming what might be called philological competence. The latter presupposes, among other capacities, a skill of getting access, through literary texture, to conceptual and cognitive structures as stable mental representations of the world, entrenched in our mind, as well as individual, emergent, ad hoc mental structures, both being accompanied by the in-built emotional patterns, which might be traced in literary text (Воробйова 2006; Воробьёва 2010). That is why, along with cognitive studies of literary discourse, more and more emphasis has been laid upon their didactic perspective ${ }^{1}$, thus giving shape to pedagogical cognitive poetics, by analogy with pedagogical grammar, pedagogical stylistics (Hall 2014; Pedagogical stylistics 2012; Zyngier \& Fialho 2016), etc. 
Within this framework, literary discourse, often viewed as a source and material for cultivating cultural literacy (Hirsch, Kett \& Trefill 1993) and developing linguistic competence in the language-through-literature classroom, becomes more and more an experimental platform. This platform tends to be used for elaborating interpretive skills of eliciting cognitive and emotive emergent structures that generate multiple senses, often ambiguous, causing the effect of emotional resonance in literary response (Воробйова 2006). Such skills, in their turn, might be viewed as a relevant instrument of strengthening the readers' creative potential for improving their speech standard, interiorising cultural gains, and developing critical thinking.

\section{Ambiguity: a spectrum of definitions and range of manifestations}

With this double, research and didactic, perspective in mind the paper will focus on the interface of tradition and new vistas in literary linguistics as one of its future prospects. The aim of the study is to work out an overarching pattern of literary text disambiguation that combines semantic, conceptual, narrative, semiotic, and other relevant analytic tools, which will ensure the grounds for a more effective interpretation of ambiguous literary discourse.

The material under study covers Woolf's shorter fiction (1989) with a particular emphasis upon her 1921 short story entitled A haunted house (Ibid.: 122-123), with its attention to "unseen webs of human relations [...] connecting people to a specific place" (Baldwin 1989: 23). The methodology employed includes a variety of techniques used for identifying and interpreting ambiguities in literary text via the combination of its semantic, conceptual, and narrative-semiotic analyses.

\subsection{Ambiguity: mechanisms and typology}

The definition spectrum of ambiguity as an intrinsic feature of literary discourse, reaching in modernism the rank of its epistemological principle (Everdell 1997: 99), is traditionally rather wide. Its most universal definition was suggested in the early 1930s by Empson in his Seven types of ambiguity (2001). According to Empson, ambiguity 
is "any verbal nuance, however slight, which gives room for alternative reactions to the same piece of language"2 (Ibid.: 1).

A more detailed definition of ambiguity was given by Darian, an American literary scholar and writer. For him ambiguity is a verbal phenomenon to which there is more than one potential meaning, and also a technique that "contains a variety of clues that point to different possibilities of interpretation" (2001: 42).

In the light of current gains in neurosciences (Zeki, Aglioti, McKeefry \& Berlucchi 1999, s.a.), according to which ambiguity implies "not uncertainty, but certainty - the certainty of many, equally plausible interpretations each one of which is sovereign when it occupies the conscious stage", Zeki claims (2006: 245) that

each interpretation therefore is as valid as the other interpretations, and there is no correct interpretation. Ambiguity therefore is the obverse of constancy. [...] In a sense, the brain accepts that there is no single essential and constant feature, but several instead.

Taking the above definitions as complementary, let us return to the initial one that, regardless of its diffuseness, which testifies, in Empson's view, to "the ambiguity of 'ambiguity"' (2001: 6), might serve as an interpretive umbrella for singling out its seven basic types in literary text. Their differentiation is presumably determined by "different levels of ambiguity dictated by neurological necessity and built into the physiology of the brain" (Zeki 2006: 246). Such varieties of ambiguity are regulated by several semantic principles. The first one, which might be called semantic polyfunctionality, is traced when "a word or a grammatical structure is effective in several ways at once" (Empson 2001: 2). The second one, that of semantic fusion, displays itself when "two or more meanings are resolved into one" (Ibid.: 48). The third, that can be referred to as semantic synchronisation, is observed when "two ideas, which are connected only by being both relevant in the context, can be given in one word simultaneously", thus producing an additional effect (Ibid.: 102) with a reference "to several different topics, several universes of discourse, several modes of judgement or of feeling" (Ibid.: 111). 
The fourth one, which comes down to semantic complication, implies that "two or more meanings of a statement do not agree among themselves, but combine to make clear a more complicated state of mind in the author" (Ibid.: 133). The fifth principle that suggests a heuristic confusion of meanings results in the effect when "the author is discovering his idea in the act of writing, or not holding it all in his mind at once" (Ibid.: 155). The sixth principle, which forms the ground for creating a semantic conflict, is put into action when "a statement says nothing, by tautology, by contradiction, or by irrelevant statements; so that the reader is forced to invent statements of his own and they are liable to conflict with one another" (Ibid.: 176). And the last principle, that of causing a semantic split, shows itself when, according to Empson (Ibid.: 192), "the two meanings of the word, the two values of the ambiguity, are the two opposite meanings defined by the context, so that the total effect is to show a fundamental division in the author's mind". This entails an impression of "the stereoscopic contradictions that imply a dimension" (Ibid.: 193), or the effect of the author's or personage's personality split reminiscent of freudism (Ibid.).

Another criterion for classifying ambiguities is their position on a scale of transparency or opacity. Neurologically, it is experimentally proved, as Zeki (2006: 266) states, that

there is a continuum in the operations of the brain, the basis of which is to seek knowledge and to instill meaning. In this continuum, we proceed from conditions where the brain has no option in its interpretation of the signals that it receives [...] to ones in which there are two equally plausible interpretations and, finally, ones in which there are many interpretations.

This observation perfectly fits Darian's (2001: 42) assumption that "ambiguity exists in varying degrees, along a sliding scale, from statements that are never explained and can never be explained - to those the reader can infer explanations for - to those that are eventually explained", which can be seen as a graded change from obscurity to indistinctness, then to indeterminacy, and further to indirection.

Empson also suggested a continuous scale of ambiguity, which is fixed in four perspectives that can be referred to as logico-psychological, cognitively hedonistic, 
combinatorial, and intentional / receptive. The former envisages a varying degree of: (i) logical or grammatical disorder; (ii) conscious apprehension of ambiguity, and (iii) its psychological complexity (Empson 2001: 48). The cognitively hedonistic angle allows to classify ambiguities into three more types: (i) "those which, once understood, remain an intelligible unit in the mind"; (ii) "those in which the pleasure belongs to the act of working out and understanding, which must at each reading [...] be repeated"; and (iii) "those in which ambiguity works best if it is never discovered" (Ibid.: 57). From the combinatorial viewpoint ambiguity can emerge if a word or phrase have: (i) "several distinct meanings"; (ii) "several meanings connected with one another"; (iii) "several meanings which need one another to complete their meaning", or (iv) "several meanings that unite together so that the word means one relation or one process" (Ibid.: 5). In terms of intention and / or reception the ambiguity scale is built according to such a sequence: "an indecision as to what you mean" $\rightarrow$ "an intention to mean several things" $\rightarrow$ "a probability that one or other or both of two things has been meant" $\rightarrow$ "the fact that a statement has two meanings" (Ibid.: 5-6).

All these numerous mechanisms of creating ambiguity in literary discourse presuppose various techniques of its resolution, which, in spite of their heterogeneity, have much in common, mainly due to their neurobiological background. According to Zeki (2006: 244),

ambiguity in art is not special to art. It is rather, a general property of the brain which is often confronted with situations or views that are open to more than one, and sometimes to several interpretations. The artist, rather than creating ambiguity, thus uses, sometimes to exquisite effect, this potential of the brain.

Thus, whether ambiguities are created or just used in a literary text does not diminish their value for multiple sense generation that varies in degrees, depending on the literary trend and / or the writer's individuality. 
2.2 Ambiguity in Virginia Woolf's short fiction: identification, interpretation, disambiguation

Woolf's short fiction, as a vivid manifestation of the role double entendres play in modernist writings, abounds in ambiguities, including those by vagueness (Empson 2001: 26) and obscure references (Ibid.: 167), i.e. the so called opaque or dark implicates, in Molchanova's parlance (2007: 149). The latter do not make the text unintelligible, even if their referents remain unclear, as they are part of the "game with the reader", in Lotman's terms (1982: 85), when the reader is ascribed a status higher or more intimate than s/he really enjoys. Such ambiguities belong to the first category singled out by Darian, i.e. to such statements, which are designed to be left nondeciphered, remaining for good (or for long) "a thing-in-itself". It can be illustrated by the description of a mysterious plasmoid substance with its glimmering emanations in Woolf's Monday or Tuesday, e.g., Flaunted, leaf-light, drifting at corners, blown across the wheels, silver-splashed, home or not home, gathered, scattered, squandered in separate scales, swept up, down, torn, sunk, assembled - and truth? (Woolf 1989: 137).

Here, it is not only the nature of the ephemeral substance that remains enigmatic but also its correlation with the search for truth as the main motif of the short story, an ideal, which remains pendant.

Along with opaque ambiguities, Woolf's shorter fiction is also rich in such ambiguous statements to which the readers, notwithstanding the fuzziness of these utterances, can consciously, by using various interpretive techniques, and / or subliminally, relying on their philological intuition, infer, ascribe, or read into the text relevant explanations, like for the fragment below, taken from A haunted house (Woolf 1989: 122-123). In this excerpt death is identified with a material object - a window pane that symbolises a borderline between the inside and outside, the warm world of home and that of the hostile universe, e.g., But the trees spun darkness for a wandering beam of sun. So fine, 
so rare, coolly sunk beneath the surface the beam I sought always burnt behind the glass. Death was the glass; death was between us (Woolf 1989: 122).

In the above passage the ambiguity as a manifestation of logical compression (Empson 2001: 31) is heightened by its functioning as an artistic detail. It brings us back to Empson who assumes that "when a word is selected as 'vivid detail' as particular for general", similarly to a window pane / glass metaphtonymically standing for death, "a reader may suspect alternative reasons why it has been selected" (Ibid.: 27), which entails a search for hidden senses presumably associated with such a detail.

In Woolf's short stories one can frequently come across ambiguous statements that in the long run are explained in the text itself, being verbalised as answers, guesses, or suggestions. Thus, discovering the mystery of the "buried treasure" in A haunted house is at first associated with light, further being reinterpreted by the narrator through other associations related to the characters' state of mind, their feelings, and emotions, e.g., Yet, the moment after, if the door was opened, spread about the floor, hung upon the walls, pendant from the ceiling - what? My hands were empty. [...] Oh, was that the buried treasure? / A moment later the light had faded (Woolf 1989: 122).

The reader's or interpreter's hypotheses concerning unresolved ambiguities can, to a great extent, be grounded in the vertical context (Гюббенет 2010: 18-40). The latter might be explicated in the writer's diaries, memoirs, etc., or construed intertextually with regard to his / her other literary works or oeuvres of other writers, as well as in literary criticism and hermeneutic commentaries. So, due to syntactical similarities between elliptical sentences in the above excerpts one can trace certain parallels in the description of the mysterious substance in Monday or Tuesday and a more transparent depiction of the ethereal substance, probably light, in A haunted house, which gives the reader a hint, though not a decisive one, as to what this substance might be. 
Quite a few ambiguities entail interpretations that "are not only many but are also sometimes contradictory" (Zeki 2006: 264). Given that, one cannot but agree with Empson who, regarding most of literary ambiguities as beautiful, assumes that if "there is contradiction, it must imply tension; the more prominent the contradiction, the greater the tension" (2001: 235). However, in my view, tension in ambiguities displays itself not only when there is a semantic or interpretive contradiction but practically always. Regardless of the very presence of contradiction or its degree, such tension gives ambiguities a particular textual relevance as triggers of the dialogue between the author and its potential or real readers.

In concrete literary texts ambiguity sites vary topologically: they can be linked to the narrator, focaliser, implied reader, and / or character, while being associated with "the author's presence, subjectivity, historicity, and linearity of the text, gender or other specific narrative or discursive features, as well as with their complex interrelations" (Mezei 1996: 2). Ambiguity may serve as an initial impulse of the author-reader dialogue as in-built in literary text or of its readers' potential dialogic response. At this, ambiguity can function as a source of tension par excellence or as part of the double mechanism based on definiteness / indefiniteness that stands behind linguistic signals of literary text addressee-orientation (Vorobyova 1996). Interestingly, the interaction of ambiguity, certainty, and uncertainty in textual response correlates, according to the neurobiological data, with the mechanisms of brain workings, which require for its adequate functioning an average level of novelty, while relying on "procrustean" nonambiguity entrenched in the neurons' activity. According to Turner and Pöppel (1988: 72), "Human information is, on the crude level of individual neurons, procrustean. [...] this insistence on unambiguity is rooted in our neurons".

\section{Virginia Woolf's $A$ haunted house: techniques of cognitive poetic analysis}

Processing and interpreting ambiguities, artistically relevant ones included, have acquired new significance with the cognitive turn in humanities (Chafe 2010), which substitutes the traditional objectivist myth of reflecting reality by the experiential myth 
of its cognising and construing. Such a change of interpretive vantage fosters a better understanding of backstage mental structures and imagery as accessible through language and text not only in theoretical terms, as a conceptualisation vector, but also instrumentally, when language and text, literary in particular, are viewed as a window into conscious and subconscious facets of the writer's mind (Ibid.).

Within the framework of cognitive poetics (Freeman 2014) and cognitive stylistics (West 2016), alongside theoretical hypotheses aimed to reveal cognitive and emotive mechanisms behind artistic effects in poetry and prose (sее Бєлєхова 2002; Freeman 2005; Stockwell 2002; Tsur 1992), much has been done in order to elaborate various techniques of conceptual analysis, which do not only allow to deepen the interpretation of literary texts, mainly modernist and postmodernist, that are particularly difficult for understanding, but also discover new facets of their authors' linguistic personalities (Колесник 1996; Semino 2006 et al.). At first, a set of such techniques, which integrates a number of sequential stages of literary text analysis, mainly short fiction, explicated in my earlier papers (Воробьёва 2004; Vorobyova 2002a), was designed to solve concrete research tasks: revealing and explaining textual anomalies, discovering the mechanisms of suspense, eliciting patterns of textual symbolism, etc. Further on, this pattern of conceptual analysis was updated in terms of its integration with more traditional techniques of stylistic and narrative semiotic analyses (Scholes 1982) to eventually suggest a flexible scheme of cognitive poetic interpretation of literary discourse.

The stages of applying such a pattern of interpretation to short fiction or fragments of lengthier literary texts envisage (see also Воробьёва 2004: 50-51):

i) identifying relevant receptive hindrances (ambiguity sites, blind spots, implicates, lacunas, textual anomalies, etc.), which might serve as interpretive clues in literary texture, followed by such procedures: 
ii) reconstructing a set of key concepts, actualised in verbal imagery and / or by other verbal means, as well as modelling their relevant configurations;

iii) inferring or construing, with regard to the established set of key concepts, which usually form a set of oppositions (e.g., LIFE :: DEATH, LIGHT :: DARKNESS, etc.), dominant conceptual metaphors, and other conceptual tropes that jointly, through their clusters, reveal the global textual concept, or megaimage viewed as a conceptual ideogram ${ }^{3}$;

iv) tracing discursive dynamics of mental spaces (Fauconnier 1994), subworlds, or text worlds (Gavins 2003; Werth 1999), which programmes the trajectory of an interpretive focus, while highlighting sense oscillations in literary text;

v) building a global network of conceptual integration (blending) (Turner 1996; Turner \& Fauconnier 2002), which fosters the eliciting of hidden and shadowed textual senses by way of their accumulation and crystallisation;

vi) defining key instances of literary symbolism in the text under study and suggesting their interpretation from the cognitive perspective;

vii) disentangling ${ }^{4}$ narrative strategies and tactics (Barthes 1977: 147) that provoke relevant sense oscillations;

viii) conceptualising the characters' narrative stances;

ix) dismantling heterogeneous layers of literary texture by means of:

a) building isotopic configurations of thematically bound words and phrases;

b) singling out rhythmically arranged syntactic chains of textual elements;

c) highlighting phonosemantic, prosodic, and syntactic iconicity; 
d) computing such configurations and chains by way of mini- or nanocorpus analysis $^{5}$ as well as presenting its results in diagrams to visualise the mechanisms of emotional resonance in the readers' literary response.

Unlike the initial stage of analysis, i.e. identifying textual clues, which is always its starting point, the rest of the stages, the list of which remains open, might follow any order, depending upon the focus of analysis and their relevance for each concrete text. Some of them might be skipped or repeated in the loops of the philological circle (Spitzer 1948: 25). If necessary, the analysis can be completed by the techniques of literary text interpretation that are grounded in possible worlds semantics (Ryan 2008), cognitive deixis (Stockwell 2002: 41-57), etc., a detailed description of which is given in Stockwell's book on cognitive poetics (2002), and modified, if necessary, for concrete research purposes.

While adapting this scheme for the tasks of literary text disambiguation, let us pass on to the analysis of Woolf's A haunted house (1989: 122-123) that abounds, as it was mentioned earlier, in various multilevel ambiguities. In a sense, this short story unfolds like a kaleidoscope of quickly changing, fleeting impressions, which, by acquiring form, colour, and sense, highlight not so much a stream of consciousness but rather motions of human soul. Indefiniteness, suddenness, unexpectedness, unpredictability, together with understatements, seem to really haunt the reader who, like the characters of the story, plunges into the state of worry and anxiety ${ }^{6}$, travelling along its narrative labyrinths in search of the answer to be discovered at the end of the story, so abruptly, suddenly, and clearly.

The key conceptual metaphor of Woolf's short story, LOVE IS LIGHT WITHIN, becomes an interpretive pivot that allows to disambiguate its variable narrative perspectives, opaque focalisation vantages, a number of local double entendres that activate the concepts of LIGHT and EMPTINESS, while bringing to the surface those narrative, imagistic, sensory, and colour motifs recurrent in Woolf's literary works, 
which highlight various facets of her creative linguistic personality (see also Воробьёва 2004).

\subsection{Identifying ambiguity sites}

Initially, the short story, in which a "lovely" couple of ghosts returns to their former home to find a hidden treasure and give it to its current dwellers, was not infrequently regarded in terms of ambiguity as a story with a variable, glimmering narrative perspective that is distributed between several narrators. Such an effect is mostly created due to the pronoun shifts (cf., Воробьёва 2004: 51; Vorobyova 2002a: 19) at the beginning of the story (you - you ... us - one - one - one; oneself - My - one My) and its final part (us - Our-we ...us - we - I-your), which blur the contours of both the narrator and focaliser, making the narrative ambiguous as to their identities, given that the text contains no personal names. This, in full compliance with Woolf's vision of human consciousness as protean, momentary, and changing, gives the story a quality of generalisation, bringing it to the limits of a parable.

Following the above tradition, let us start the disambiguation procedures with disentangling the story's initial narrative perspective that rotates around the motif of emptiness, which tends to prevail in the first part of the text, by applying the mental space toolkit (cf., Воробьёва 2004: 51-52). This motif, implying physical and spiritual lack of the desired possession, connects and brings together the space of the house (the house all empty), the space of the garden (What did I come here for? What did I want to find?), and that of the human body - here the "space" of the narrator's hands ( $M y$ hands were empty. ... My hands were empty). Thus, the narrative voice (you - us - one $-I$ ) and the focalisation vantage turn out to belong to one and the same person, reflecting not so much the multiplicity of the narrative perspectives, variability of focalisers, and textual polyphony but rather deictic shifts between the manifestations of narrative stance - a fuzzy narrative position of the character in the altered state of consciousness: the narrator is either asleep or in reverie, either dreaming through the story read in the book, or just daydreaming (see Fig. 1). 


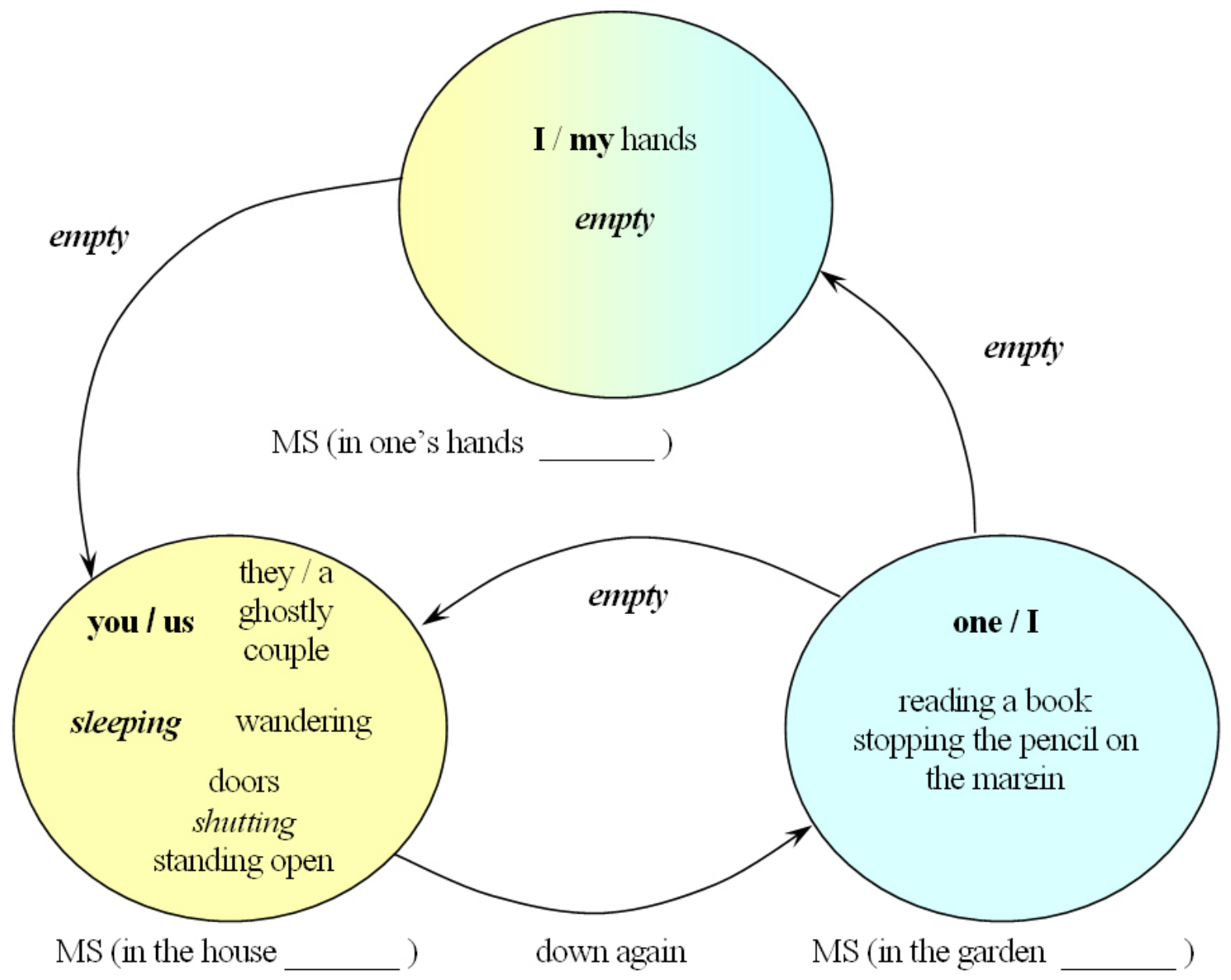

Figure 1. Emptiness as the object of focalisation

Along with the pronoun shifts, also traced in the final part of the text (their light lifts the lids upon my eyes), which make it unclear whether it is the ghosts who emanate light or it comes from within their lantern, the story suggests other varieties of ambiguity, which might serve as textual clues in its further disambiguation (see also Vorobyova 2002a: 19). Among them:

- cross-referential ambiguities that permeate the story's texture, giving rise to the narrator's final insight as to what the buried treasure is, e.g., left it - 'It's upstairs' looking for it - 'Now they've found it' - 'Perhaps it's upstairs then?' - they had found it - 'Oh, was that the buried treasure?' (Woolf 1989: 122);

- referential ambiguities that initially (a) concern the search for the hidden treasure, which is first assumed to be emanations of light and then crystallises as the energy of love, to further (b) characterise the house as a living being with its pulse beating evenly 
or unevenly as the case might be, cf., (a) spread about the floor, hung upon the walls, pendant from the ceiling - what? - 'The treasure buried' - the buried treasure? - Out in the garden then? - 'The Treasure yours.' - 'Here we left our treasure-' - 'Oh, is this your buried treasure?' (Ibid.: 122-123); (b) [there was a door shutting] the pulse of the house beat softly - the pulse stopped short - the pulse of the house beat gladly - The doors go shutting far in the distance, gently knocking like the pulse of a heart (Ibid.);

- predicative ambiguities, which (a) remain fuzzy in case of juxtaposing death and a window pane or (b) result in the narrator's and readers' synergetic insight about the true nature of the buried or lost treasure, cf., (a) Death was the glass (Woolf 1989: 122); (b) '[... your buried treasure? The light in the heart' (Ibid.: 123);

- locative ambiguities that allow a double interpretation of the respective prepositions as topological landmarks (behind the glass - in the house or outside? between us literally or figuratively? parting people or finally bringing them together?), e.g., (a) So fine, so rare, coolly sunk beneath the surface the beam I sought always burnt behind the glass (Woolf 1989: 122); (b) death was between us (Ibid.).

Identifying and bringing together ambiguity sites in the story's texture create the empirical basis for the further stages of discourse disambiguation, dwelt upon in more detail in the sections below.

\subsection{Reconstructing the story's key concepts}

The main techniques of reconstructing literary concepts and their configurations may be grouped into five categories: 1) the technique of metadescription (Кагановська 2002; Степанов 1965: 289-297) that dates back to Vinogradov's analysis of poetry. This technique envisages construing an inferential, i.e. bottom-up or top-down, hierarchy of imagery up to or down from the resultant / initial metaimage as the text global concept; 2) the technique of clustering; 3) the technique of building up 
associative networks (Ніконова 2007) by way of establishing "synaptic" connections between key concepts of a literary text according to their associative superposition; 4) the technique of cognitive emotive analysis grounded in iconicity (Burke 2001) as a source of emotional resonance in literary response (Воробйова 2006); and 5) the technique of multimodal analysis, grounded in the in-built intersemioticity of literary text and the holographic nature of literary concepts (Воробьёва 2010; Vorobyova 2017).

Combining in this case study the two former techniques, disambiguation at the current stage of analysis proceeds from metadescription used to reconstruct dominant concepts of the short story and passes on to concept clustering employed to outline their relevant configurations.

In all probability, the interpreter would tend to restore the story's conceptual dominants gradually, while following the ghostly couple's trajectory of searching for the lost treasure. The trajectory of their quest looks like a curved line - moving from room to room, up to the attic, down into the garden, then again to the sitting-room, back to the garden, and further to the bedroom with those asleep, for whom the dead souls intend their buried treasure. The key concepts, those of LOVE and LIGHT, along with the adjacent ones of LIFE, DEATH, SLEEP and AWAKENING, SEARCH and FINDING, JOY and SADNESS, EMPTINESS and FULLNESS, are manifested in the text differently (see hereinafter Воробьёва 2004: 53). The concept of LOVE is named directly only once - Love upon their lips, being accompanied by the mention of endless kisses (Kisses without number). However, implicitly this concept seems to permeate the whole story through the symbolism of light, reaching the peak of the LOVE / LIGHT unity in the final phrase of the text: 'Oh, is this your buried treasure? The light in the heart' (Woolf 1989: 123). Similarly to LIGHT, quite a few recurrent mentions of AWAKENING punctuate the story's texture, appearing at the very beginning of the short story (Whatever hour you woke), somewhat later in the text (or we shall wake them ... But it wasn't that you woke us), closer to its denouement (whispering not to 
wake us ... Waking in the morning-), and in its culmination ending (Waking, I cry). These verb-participle dotted repetitions (woke ... woke... waking in the morning ... waking) frame the text semantically and compositionally, transferring it from generalised atemporality into the mode of "actual" reality, which strengthens the effect of insight, or the aha-effect, experienced by both the protagonist and the reader as a direct manifestation of discourse disambiguation.

The other of the two dominant concepts, that of LIGHT, can be traced in the isotopic chain (the light - a wandering beam of sun - the beam...burnt - the stars - moonbeams - the beam of the lamp - the candle burns - Silver between the trees ... - the lantern - their silver lamp - the flame - wild beams of moonlight - their light lifts the lids The light in the heart), which starts halfway through the story as a hint to deciphering the referential ambiguity in the description of the mysterious substance that fills in the house and reaches its top, like an emotional crescendo (Tsur 1992: 431), in the final part of the story. The unfolding of the above chain is accompanied by regular sensory fluctuations, where the changing intensity and brightness of light evoke associations with summer warmth that is almost over (the apple only turned its yellow side), cold wind (The wind roars up the avenue) that brought parting (leaving the house) and death (death was between us), with silvery rain (the rain slides silver down the glass), a quiet burning of the candle (the candle burns stiff and still), and that sharp insight (waking, I cry), which the narrator experiences, suddenly realising what the most significant life treasure is.

The concept of LIFE, unlike other key concepts of the story, has no direct verbal manifestation but for referentially close temporal markers such as Long years -, When summer came -, and In winter snowtime -. However, this concept, in Stepanov's parlance (2007: 68), seems to "hover over" the story's texture ${ }^{7}$, as if shaping its semantic and emotive aura, which is generated (i) by a multitude of fragmentary, fleeting impressions of the world around, of the house interior, and the narrator's bodily and sensory perceptions, coming intraceptively (My hands were empty) or as if from 
the outside (Our eyes darken; ... the faces that search the sleepers and seek their hidden joy), - as well as (ii) by the juxtaposition of LIFE with the whole spectrum of associations linked to DEATH.

The latter is verbalised in the story's texture in the twofold way: 1) convergently, through a direct refrain - Death was the glass; death was between us, along with the depiction of bad weather (wind, darkness, rain, wild flashes of moonlight), interrupted by the painful memories of the ghosts wandering about the house in search of their buried treasure, and 2) divergently, via (i) the staccato usage and / or repetition of words and phrases that (a) belong to the thematic field of "Death", such as "ghost", its derivatives and associates (a haunted house ... a ghostly couple... the ghostly couple...we see no lady spread her ghostly cloak), "buried" (The treasure buried ... Oh, was that the buried treasure? ... Oh, is this your buried treasure?), "darkness" (darkness ... the rooms were darkened), or (b) represent the respective motifs, those of loss (Here we left it ... My hands were empty ... Here we left our treasure), departure (He left it, left her), candle (The candle burns stiff and still), and extinguishing (the light had faded); (ii) implications of ephemerality (Not that we could ever see them), and (iii) associations with the concept of SLEEP in its direct and inferred verbal manifestations (or we shall wake them ... But it wasn't that you woke us ... Here we slept ... Sound asleep ... Here ... sleeping).

Similar ways of actualisation are characteristic of other key concepts in the story, where the divergent manifestations of SEARCH ('Here we left it'... 'Oh, but here too!' 'It's upstairs' ... 'And in the garden' ... 'What did I come here for? What did I want to find?' ... 'Perhaps it's upstairs then?' ... sought the house ... the ghostly couple seek their joy...the faces that search the sleepers and hidden joy) and FINDING / RECOVERY ('Now they've found it' ... But they had found it in the drawing-room.... Oh, was that the buried treasure? ... 'Again you found me' ... '...Here we left our treasure - '... 'Oh, is this your buried treasure?...') combine with the convergent realisations of JOY (wandering through the house, opening the windows, whispering not to wake us, the 
ghostly couple seek their joy ... seek their hidden joy) and SADNESS (Long they look and deeply. Long they pause. ... 'Long years ${ }^{-1}$ he sighs). The two latter echo back to the concepts of FULLNESS (The apples were in the loft ... spread about the floor, hung upon the walls, pendant from the ceiling - what?) and EMPTINESS (My hands were empty, etc.), making the final insight even more salient and unambiguous.

A significant feature of the short story under analysis, which complicates its disambiguation, is that key concepts tend to be manifested in A haunted house cumulatively up to their fusion. It is in the line with Deleuze and Guattari's assumption that (1994: 79) "a concept lacks meaning to the extent that it is not connected to other concepts and is not linked to a problem that it resolves or helps to resolve". A more detailed view on verbal manifestations of the above concepts testifies to their polyfunctionality and polysemanticity, as one and the same phrase not infrequently gives access to several key concepts, e.g., My hands were empty, which brings together the motifs of life, death, sadness, loss, a possibility of looking for and finding the desired object, thus heightening the ambiguity of suchlike utterances with regard to the respective concepts.

Simultaneity of concepts realisation makes it feasible to resort to building up associative networks of key concepts in order to establish their configurations. Such configurations might be called synaptic, as they graphically look like a network of synaptic connections, where the links are formed by the polyfunctional verbal markers of respective concepts, which outline, depending upon the degree of complexity of such links, the visual image of a circle, rhizome, or the like. The possibility of using this technique is grounded in the assumption that "every concept relates back to other concepts, not only in its history but in its becoming or its present connections" (Ibid.: 19).

However, here I will stick to a more traditional technique of combining the key concepts - the technique of their cluster structuring, based on the category shifts, 
superposition, and / or contrasts as mechanisms that stand behind various conceptual tropes.

\subsection{Construing conceptual tropes}

Such construals usually presuppose two main ways of conceptualisation - analogical (metaphorical) and associative (metonymical), not infrequently in their combination in metaphtonymies, sometimes completed by conceptual contrasts (oxymora).

Given the initially chosen motif of the correlation between light and love in the context of life and death, the texture of $A$ haunted house tends to activate three pivotal groups of metaphors (see Table 1 below), which jointly shape the conceptual space of the short story (cf., Vorobyova 2002a: 19-20), - LIFE IS LIGHT / A PATH / A SEARCH OF VALUES / AWAKENING; DEATH IS DARKNESS / A STOP / EMPTINESS / SLEEP; LOVE IS AWAKENING FROM SLEEP / HIDDEN JOY / A TREASURE / A QUIET LIGHT FROM WITHIN, e.g.,

Table 1. Inventory of conceptual metaphors

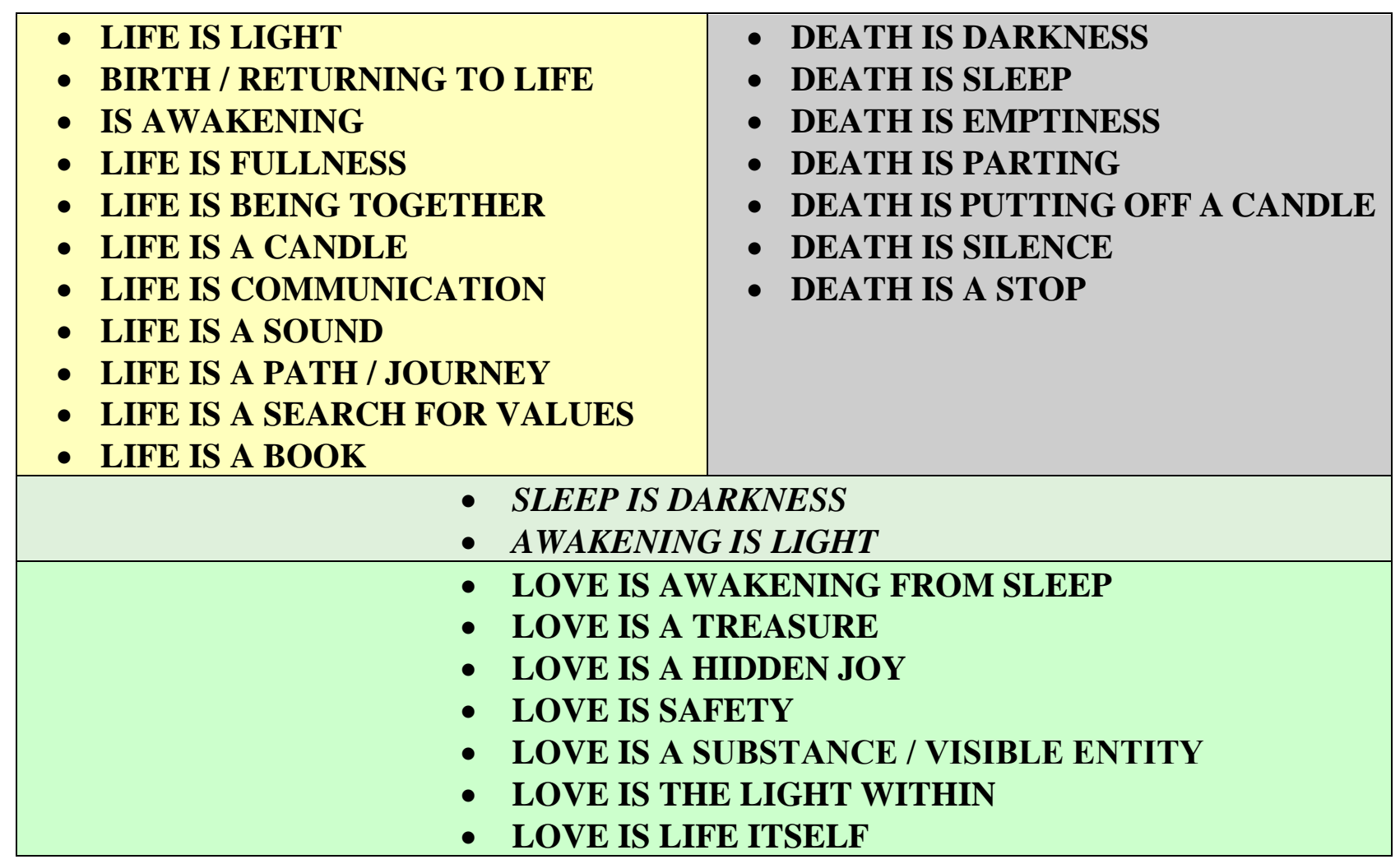


Counterpoint to the above metaphorical clusters comes the imagery linked to the concept of HOME / HOUSE. Thanks to the fact that home / house acts as a connecting link between generations (hundreds of years ago), fixing the key moments of human life, which are recurrent through the times (sleeping; in the garden reading; laughing, rolling apples in the loft), it fosters the activation of the conventional conceptual metaphor LIFE IS A CYCLE that finds its realisation in the description of daily changes, oscillations of space, changes of seasons, and fluctuations of heartbeat ('Here we slept,' :: 'Waking in the morning -'; 'Upstairs - ':: 'In the garden -'; 'When summer came $-^{\prime}:$. 'In winter snowtime -'; like the pulse of a heart). The background for the above conceptual trope is formed by the HOUSE / HOME IS A LIVING BEING metaphor, where the personified space of the house "communicates" with its current and former dwellers, appeasing them, empathising with them, which is reflected in its heart beat (The pulse of the house beat softly). The emphasis laid upon the anthropomorphic properties of the house fosters the disambiguation of its pulse motif as the house seems to take pride in preserving its former hosts' treasure ('Safe, safe, safe,' the pulse of the house beats proudly), while feeling elated and agitated realising its role in the lives of its inhabitants ('Safe! safe! safe!' the pulse of the house beats wildly) (cf., Vorobyova 2002a: 20).

The tropology of house / home is accompanied in the story by the tropology of light, where the latter stands out either as a hidden or apparent object of search (the beam I thought) or as a liquid in a container (Moonbeams splash and spill wildly in the rain). The cool and fleeting moonlight, ready to pour over, is contrasted to the quiet burning of a candle behind the window (The candle burns stiff and still). This contrast is heightened by the alliteration, assonance (splash and spill; stiff and still), and rhyming (spill - still). Standing aside is the synesthetic visual-auditory image of the sound bubbles (from the deepest welds of silence the wood pigeon drew its bubble of sound), which, employing the traditional container metaphor verbalised as "a well of silence", is transformed into the conceptual oxymoron SILENCE IS A CONTAINER FOR SOUND. Conventional metaphors, the list of which can be further continued (including 
those with the conceptual referents of TRUTH and SEARCH FOR TRUTH, MEMORIES, and LOSS), are supported in the story by the idiosyncratic Woolfian figuration, drawing parallels between life and a book as well as life and background sounds of nature vs. those of technology that oppose the motifs of standstill, emptiness, and silence as manifestations of decay, depression, or death. e.g., And then, tired of reading, one might rise and see for oneself, the house all empty, the doors standing open, only the wood pigeons bubbling with content and the hum of the threshing machine sounding from the farm (Woolf 1989: 122); My hands were empty. The shadow of a thrush crossed the carpet; from the deepest wells of silence the wood pigeons drew its bubble of sound (Ibid.).

These metaphor clusters are accompanied in the story by the associative chain of metonymical motifs, related to people as containers for feelings and emotions, to a house as an analogue of human inner world and the universe, a door as a portal between the worlds, ghosts as mediators between the worlds, a book as a substitute of altered or liminal state of consciousness, a window as a border between the worlds, a source of light (a lamp / candle / the moon) as a source of energy, light as a source of intuitive knowledge and epiphany ${ }^{8}$. The most ambiguous within the glimmering narrative perspective of Woolf's short story seems to be the idiosyncratic passage below that tells about a book, which fell down into the grass, e.g., But it wasn't that you woke us. Oh, no. 'They're looking for it; they're drawing the curtain,' one might say, and so read on a page or two. 'Now they've found it,' one would be certain, stopping the pencil on the margin. And then, tired of reading, one might rise and see for oneself, the house all empty [...] 'Perhaps it's upstairs then?' The apples were in the loft. And so down again, the garden still as ever, only the book had slipped into the garden (Ibid.).

This ambiguity might be partially resolved, if the above excerpt from the beginning of the story is compared with the fragment of the ghosts' nostalgic dialogue at the end of the text, which revives their memories of the then happy marital life where there was a similar garden, the same attic filled with apples, and, what is most important, the 
feeling of carelessness the current dwellers of the house lack, e.g., 'Here,' she murmurs, 'sleeping; in the garden reading; laughing, rolling apples in the loft. Here we left our treasure $-^{\prime}$ (Ibid.).

The effect of déjà vu, provoked by the superimposition of at least two mental spaces the oneiric space of those sleeping in the house now and the hauntological space ${ }^{9}$ of its former dwellers, lifts the layer of ambiguities created due to the variable narrative perspective of the story. However, it brings to the foreground another ambiguous layer - the tropological one that gives access to the conceptual oxymoron of DEATH IS A REBIRTH OF LOVE. The latter integrates a paradoxical conceptualisation of death as another form of life (DEATH IS AFTERLIFE), as a rebirth (DEATH IS REBIRTH) and love as a process that envisages a chance of its rethinking and re-evaluation, which can be inferred from the conventional conceptual metaphor LOVE IS A PATH. It turns out that to realise a true value of love one ought first to lose it while still alive, and then, after death, in one's afterlife, not only regain it, but also convey its value to those who are still alive but without a true understanding of what love is.

To illustrate the way such realisation occurs, let us make another attempt at the reconstruction of the story's conceptual skeleton, this time in terms of mental space dynamics.

\subsection{Tracing discursive dynamics of mental spaces and text worlds}

The shift in focalisation, the object of which, initially emptiness, is gradually substituted for by light, makes it possible to trace the dynamics of mental spaces in the verbal texture of the story through the recurrent shuttling of narrative loci (see also Воробьёва 2004), i.e. the locus of the house (in the drawing room) and that of the garden (Out in the garden then?), which results in penetrating into the body locus here the "heart locus" that metonymically stands for human soul (The light in the heart). Such oscillations of the narrative focus rotate around the motif of glass - first as the window pane reflecting late summer light in its warm colours (The window panes 
reflected apples, reflected roses; all the leaves were green in the glass. ... the apple only turned its yellow side), as a transparent border between the house with its soft beat of the pulse of life ('Safe, safe, safe,' the pulse of the house beat softly), and the garden as part of the world, still friendly at the moment (cf., Vorobyova 2002a: 20). With light fading and the colour palette changing from warm to cool the window pane turns into a rigid frontier, which separates the house and its interior, still warm, from the cold alien world outside, separates life from death (Death was the glass; death was between $u s)$. The clue to lifting this predicative ambiguity, emphasized by inversion, which results from ascribing a mundane window pane mystical properties, is provided by the chain of mental space connectors that shape the correlative pair reflects :: separates (see Fig. 2).

Further on, this chain is modified by the implicit connector contains associated with the transparent glass borders of the lamp and lantern, which, together with the window pane and human hands, do not only contain a flame that gives light, but also protect it from external forces (But the beam of the lamp falls straight from the window. ... His hands shield the lantern). The change of the colour palette - from winterly scary to silvery cool, caused by the moonlight glimmer ('Silver between the trees -' ... silver lamp ... Wild beams of moonlight), no longer threatening, - creates the background for the story's climax - the dominant heart-and-soul space, emanating a steady warm light (The light in the heart). In this way the text itself resolves its plot-creating referential ambiguity (spread about the floor, hung upon the walls, pendant from the ceiling what? ... 'The treasure buried;' ... the buried treasure? ... Out in the garden then? 'The Treasure yours.' ... 'Here we left our treasure -'), suggesting the answer to the question of what the lost treasure is ('Oh, is this your buried treasure?').

Viewing the short story from a somewhat different yet adjacent angle, that of text worlds theory (Gavins 2003; 2007), let us come back to the initial ambiguous narrative perspective and, skipping the complicated notation diagrams of text worlds analysis, trace the dynamics of the story's text worlds switching. 
window pane

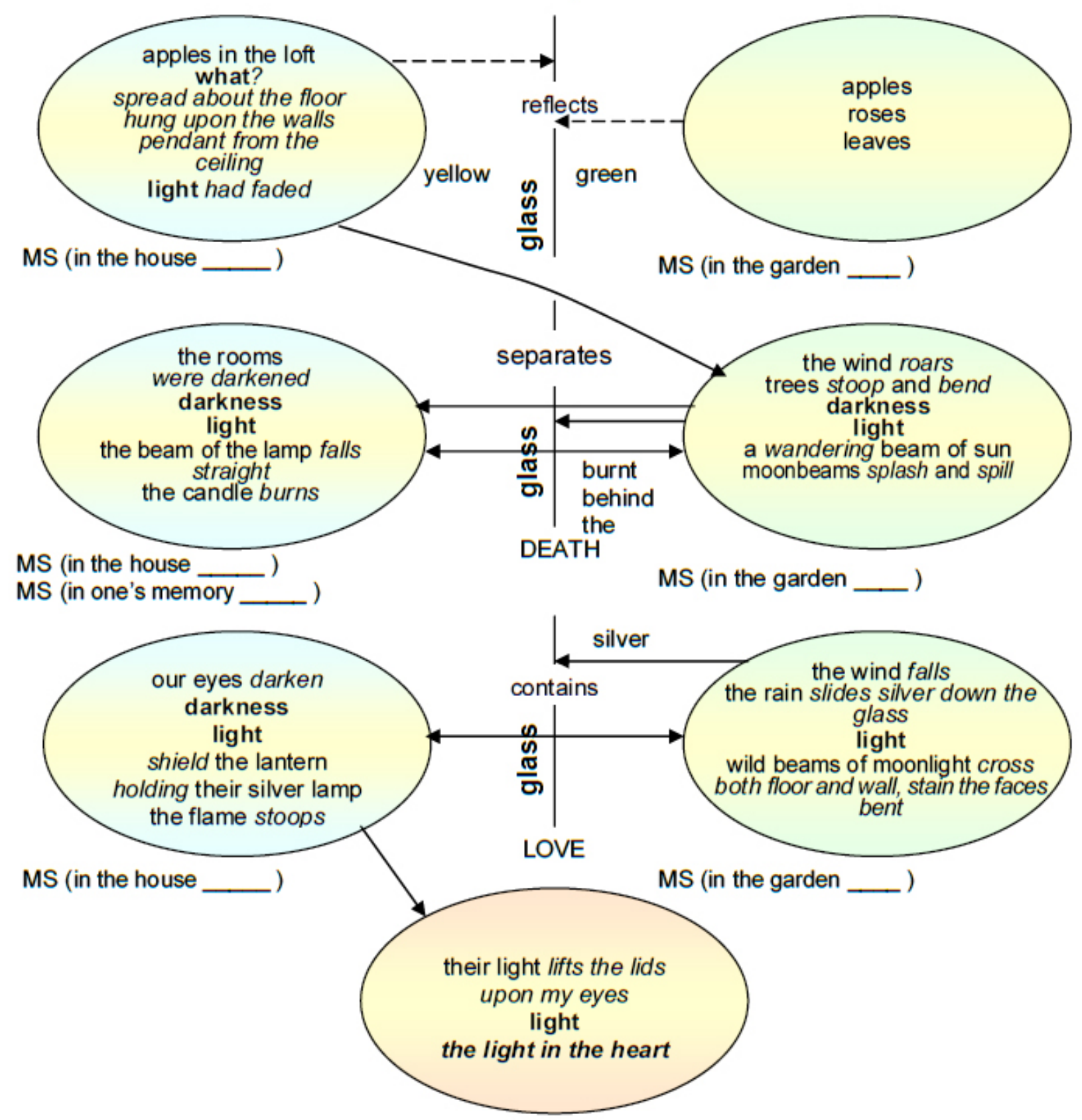

MS (in one's heart __ )

Figure 2. Dynamics of mental spaces: Light as the object of focalisation

Unlike possible worlds in literary text (Doležel 1998; Eco 1990) as imaginary construals based on the idea of mimesis, text worlds (Gavins 2003; 2007; Werth 1999) are grounded in the unity of factual (real) and fictional discourses of three levels: discourse worlds, or the worlds of real or hypothetical participants of literary communication, text worlds, or their individual mental representations of text by which 
the discourse is interpreted, and subworlds associated with various characters or signalled by the markers of subjectivity (Gavins 2003: 129-130).

Text worlds are construed by combining world-building elements, particularly verbal markers of time and place that are described or mentioned, and function-advancing propositions, related to actions, events, states and processes that push the discourse world forward (Ibid.: 130-131). According to Gavins, the sub-world layer of literary text includes world-switches and modal worlds per se. The former are flashbacks or flash-forwards as well as direct speech markers of alternate place or time (Ibid.: 131).

Given the protean contours of the ghosts' subworld, one could expect a rapid change of world-building elements, but instead a set of its function-advancing propositions undergoes constant changes. To put it differently, the setting, slightly changeable in time, remains stable spatially, being confined to the house and garden, however, it gets saturated with numerous small events: doors are opening and shutting, the ghosts are wandering from room to room, lifting something, unlocking something, whispering, searching for something, finding something, moving again (door shutting... they went... lifting... whispered... looking for it.. found... moved, etc.). Then, the major narrative focus moves towards the subworlds, the switching between which is marked by the pronoun shifts mentioned earlier, that change the focalisation vantage, making it ambiguous and thus creating interpretive challenges.

The point of departure for the story's interpretation is the initially introduced text world that outlines its narrative background - the setting, the main characters, and their actions. The first subworld switch is marked by the ghosts' direct speech, which fosters narrative intimisation through zooming in - we do not only "see" the apparitions but also seem to hear them, which involves the hypothetical reader into their private world of virtuality. This might have continued further - we would have learnt the story of the haunted house directly from the haunters but for modal worlds of other characters inculcated into the texture. The ghostly couple point to someone sleeping whom they 453

ISSN 2453-8035

DOI: 10.1515/lart-2017-0011 
do not want to wake up and who seems central to the narrative, launched by a wouldbe external observer (Whatever hour you woke). The question remains why this someone appears both as a group of people, or at least a couple, and as an individual person (us, my hands).

The situation gets even more complicated due to the subworld switching through the change of location - it is now the garden, then back to the house, and into the garden again. Each of the subworlds is characterised by the variable modality, and the house gradually acquires the character's status - this is no longer just a locus but a living being that reacts to the events within and outside.

Notwithstanding the fact that the ghostly couple are searching for the treasure, which was lost long ago in the context of the narrative now, temporal world-switches occur in the text only twice, excluding the word "buried", which, if taken literally, might be associated with a view into the past. The double effect of estrangement and intimisation is strengthened by the contrast of the initial and medial parts of the story. The former narrates the events in the past tense, some of them are represented as hypothetical, with sporadic jumps from one temporal and / or locative space into another, while in the part that follows the events are arranged linearly, in the present tense, being heightened by the intimacy of the heartbeat, cf., the pulse of the house beat softly vs. the pulse of the house beats proudly.

Roughly divided into three parts, the short story in its final part, starting with the kinaesthetic auditory image of wind (The wind roars up the avenue), abounds in the worlds' switches between the house and the garden against the background of the characters' modal subworlds that get gradually reduced in scope. At a certain point the subworlds of the house and the garden get fused, as located on a seemingly homogenous plane. It happens when the moonlight beams fall first upon the floor, then a wall, and then illuminate the ghosts' faces. The climax is reached when light awakens the one for whom the treasure, the light within, has been searched for (Oh, is this your 
buried treasure? The light in the heart). It becomes clear that there is just one narrator in the text, who presents the events as seen from different vantages - first as an external, uninterested observer, then in line with his / her personal stance, describing the ghosts' search for the lost treasure through the observer's internal vision. Such a change of perspectives, together with numerous subworld-switches, is neither accidental nor unusual. It is used to artistically construe the workings of the human mind, when we seem to look at ourselves as if from aside, trying to guess what others might say or think about us, or even adopt a perspective of some imaginary entity outside or within our body and brain.

\subsection{Building the dominant conceptual integration network}

Eliciting hidden metaphorical and non-metaphorical textual senses in all their nuances for the sake of subtler disambiguation of literary discourse requires an interpretive finetuning, which might be achieved through building conceptual integration networks (blending). In its classical version (Turner 1996; Turner \& Fauconnier 2002) this technique includes such procedures as: 1 ) defining the underlying pattern of correlation between input spaces representing textually highlighted experiential domains; 2) their structuring with regard to a conventional frame or conceptual trope based on some analogy; 3) organising the generic space in accordance with the chosen pattern; 4) concretising the structure of each input space according to the chosen pattern; 5) establishing the correlation between equipotent items of input spaces; 6 ) computing the degree to which these items get fused in the blended space or defining the vector of their substitution; 7) inferring the emergent meaning as a new non-additive sense according to the logic of the blend (Turner \& Fauconnier 2002: 40-48).

Addressing the dominant conceptual integration network of the short story (see Fig. 3), where the generic space is structured as the frame "Transition from the passive into active state" (see also hereinafter Воробьёва 2004: 53-54) due to perceiving energy (here light) as a source of vitality, assurance, and protection ('Safe! safe! safe!' the pulse of the house beats wildly), makes it possible to bring together two input spaces: that of 
the sleeping in the house and that of the ghostly couple, which embody comparable altered states of consciousness, oneiric and thanatotic.

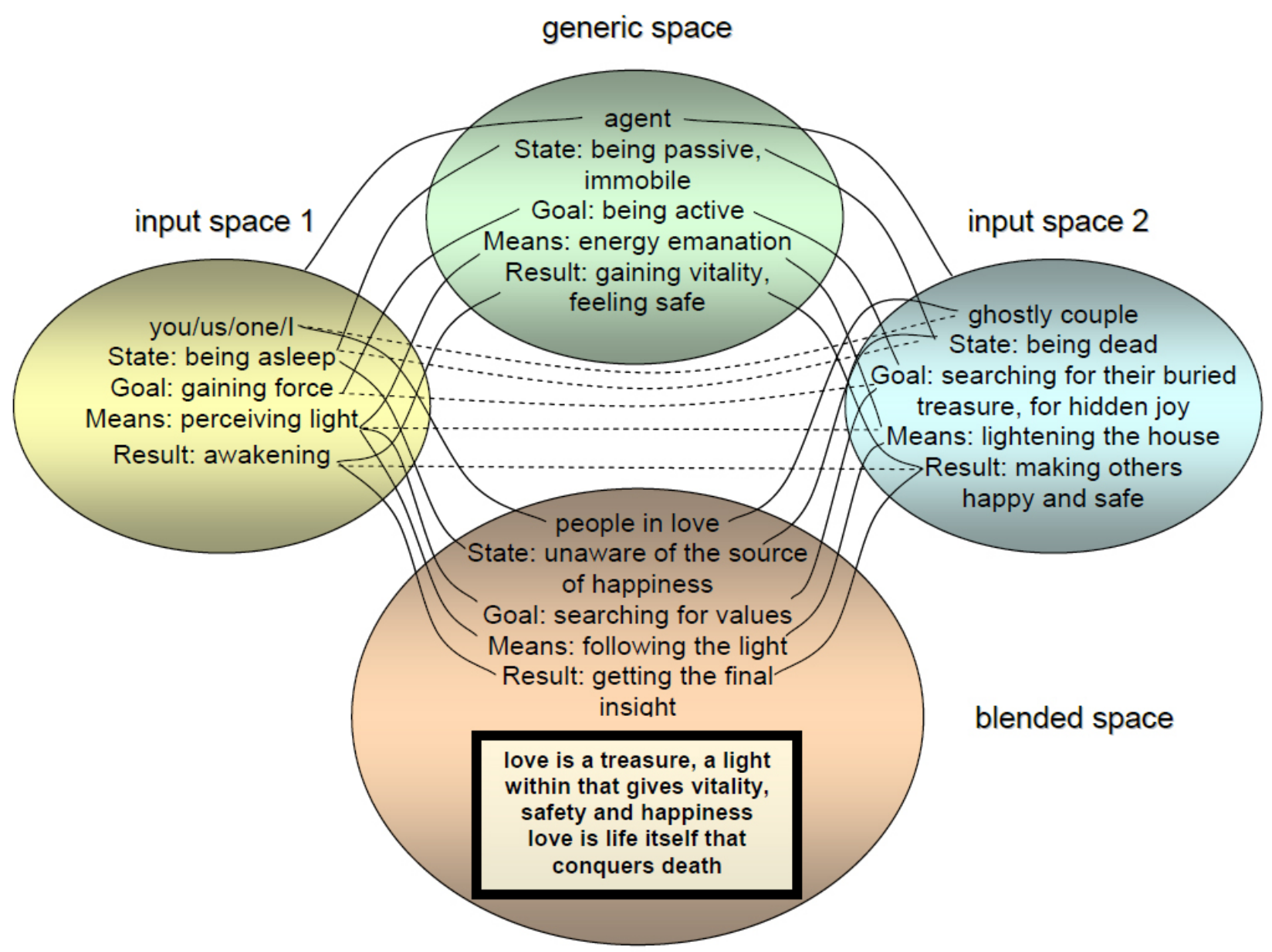

Figure 3. The conceptual integration network: Love is life that transcends death

The cross-projection of three mental spaces allows the structuring of the blended space according to such slots: the agent/s - those in love (you / us / one / I - a ghostly couple - people in love); the state - not realising where happiness comes from (being passive / immobile - being asleep - being dead - unaware of the source of happiness); the objective - finding true values (becoming active - gaining force - searching for their buried treasure / for hidden joy - searching for values); the means of reaching the objective - following the source of light (energy emanation / absorption - perceiving light - lightening the house - following the light); the result - achieving an insight (gaining vitality / feeling safe - awakening - making others happy and safe - getting 
the final insight). Such an algorithm crystallises the hidden textual sense: love is a treasure, light from within that gives vitality, safety, and happiness; love is life itself that conquers / transcends death. The inferred sense evokes the biblical interpretation (The Holy Bible 1991) of love as God and God as love, which overcomes fear, e.g., 8. He that loveth not knoweth not God; for God is love. [...] 12. No man hath seen God at any time. If we love one another, God dwelleth in us, and his love is perfected in us. [...] 18. There is no fear in love; but perfect love casteth out fear [...]. (1 John 4:8, 12, 18), as well as conceptualising God as light, e.g., "5. [...] God is light, and in him is no darkness at all." (1 John 1:5).

What makes this stage of analysis specific is a variability of the dominant conceptual integration networks, which may principally diverge from the prototypical one, in case the interpreter chooses a different pattern for structuring the generic space. For instance, it can be the idea of human consciousness limits, when a person cognises the world only subconsciously, not infrequently finding him/herself locked behind the glass or door of consciousness, where the wandering of ghosts might be taken as analogous to philosophical wanderings in search of true knowledge. Or it might convey a complementary message, when the pivotal idea that organises the basic frame is retained while acquiring in its different versions some additional overtones. Thus, the short story under analysis may widen the range of its interpretations when the emphasis is laid on its characters' state not solely as passive but as primarily altered, close to oneiric, that verges on sleep or reverie, or wider, liminal ${ }^{10}$ (Тихомирова 2015; Ratiani 2007; Turner 1964; 1974). The latter characterises the protagonist as being neither here nor there, which is manifested through the feeling of uncertainty, doubt, being physically, intellectually, or emotionally captive. Thus, we might also ascribe the narrative and semantic ambiguity of the short story to the dominance of $\boldsymbol{a}$ liminal narrator as a variety of liminal personae (Turner 1964: 6).

Liminality of the narrator is not a peculiar feature of Woolf's A haunted house. Moreover, it can be considered idiosyncratic for the writer's narrative style in her other 
short stories, such as, e.g., The mark on the wall, where the narrator, sitting by the mantelpiece, charmed by its fire, gets immersed in viewing a mysterious spot on the sitting-room wall, the mark that eventually turns out to be a snail. Narrative liminality can be also observed in Monday or Tuesday, where the reader comes across the mention of a fireplace, a book, and immersion into reminiscences, which accompany the narrator's search for truth. Some elements of liminality characterise the protagonist's narrative stance in Woolf's A simple melody, when the character, being immersed in his fancies prompted by a painting and the sounds of violin, moves from reality to virtuality, ruminating on human values (Vorobyova 2017).

In each of the above and similar instances, liminality is provoked by or linked to some symbols - those of fire, water, flight, etc., the interpretation of which constitutes another stage of cognitive poetic analysis in terms of literary text disambiguation.

\subsection{Defining the key literary symbols}

Given the density of $A$ haunted house texture, quite a few of its images and artistic details become symbolic, which particularly concerns the imagery of house / home and lantern / lamp / candle as objects that emanate light and warmth. Semantic contiguity of these images in their symbolic dimension can be accounted for not only by their links with the tropology of life and death, crucial for the story under analysis, but also by their phenomenological connections, revealed in detail in Bachelard's The poetics of space (1994) and The flame of a candle (1988) where the image of house and the motif of candle, along with that of lamp, also important for this short story, become pivotal.

Addressing Bachelard's poetics at this stage of analysis can be explained by its closeness to the modernist vision of human imagination (related, primarily, to the individual experience), with its "moments of vision", or epiphanies, provoked by material anchors (e.g., The mark on the wall) or natural elements that give rise to fancy- 
born illusions (e.g., A simple melody), insights or liminal states, associated, in particular, with literary symbols.

Returning to Woolf's key symbols, one cannot help wondering how close in topophilia (Bachelard 1994: xxxv), i.e. love of space, literary and philosophical interpretations of house / home in the analysed story and in Bachelard's poetics come. Both here and there the house is interpreted as a happy inhabited space, "defended against adverse forces" (Ibid.), where "the non-I [...] protects the I" (Bachelard 1994: 5): this space "nearly always exercises an attraction. For it concentrates being within limits that protect" (Ibid.: xxxvi). What is most important is that it represents "the topography of our intimate being" (Ibid.), reflecting "a phenomenology of what is hidden" (Bachelard 1994: xxxvii) in the context of "the intimate values of inside space" (Ibid.: 3). The house itself "constitutes a body of images that give mankind proofs or illusions of stability" (Ibid.: 17), cf., Wandering through the house, opening the windows, whispering not to wake us, the ghostly couple seek their joy. / 'Here we slept,' she says. And he adds, 'Kisses without number.' 'Waking in the morning-' 'Silver between the trees ${ }^{-{ }^{\prime}}$ 'Upstairs ${ }^{-1}$ 'In the garden-' 'When summer came-' 'In winter snowtime-' [...] / [...] 'Look,' he breathes. 'Sound asleep. Love on their lips.' (Woolf 1989: 123); 'Safe, safe, safe,' the pulse of the house beat softly. 'The treasure buried; the room ...' the pulse of the house stopped short. [...] / [...] 'Safe, safe, safe,' the pulse of the house beat gladly. [...] / [...] The doors go shutting far in the distance, gently knocking like the pulse of a heart. / [...] 'Safe, safe, safe,' the pulse of the house beats wildly (Ibid.: 122-123).

The specificity of the story under analysis is in part determined by the shift of its narrative focus from the agents that lack vitality onto the space of their "real" or virtual coexistence, where the house becomes a common living space for the ghosts and people, exactly in such an order. It is not accidental that the word "house" as a designation of a bounded space is foregrounded in the title of the short story as its strong position, being additionally highlighted by alliteration (haunted - house), and 
then gradually symbolised. Against the background of physically passive or even disembodied creatures the house is emphatically personified: it has a heart that beats evenly or unevenly, which programmes the broken rhythm of the narrative. As a result, it is the human beings become part of the space both as their habitat and as a source of energy, not vice versa.

Interestingly, Bachelard's approach to material embodiment of values, constituting another symbolic entity of Woolf's story, according to which in the house of memories, the house where you were born "the values of intimacy are scattered, they are not easily stabilised, they are subjected to dialectics" (1994: 14). Such a parallel makes it possible to specify the interpretation of the referentially ambiguous depiction of the plasmoid substance given earlier, which "spread about the floor", "hung upon the walls", and "pendant from the ceiling", supporting another of Bachelard's assumptions: "But if a house is a living value, it must integrate an element of unreality. All values must remain vulnerable, and those that do not are dead" (Ibid.: 59). Cf. also, 'Here we left it,' she said. And he added, 'Oh, but here too!' 'It's upstairs,' she murmured. 'And in the garden,' he whispered (Woolf 1989: 122).

In its symbolic dimension, the house as a primordial world, a body and soul, a state of mind, is fragmented in Woolf's story into a number of images (doors, loft, rooms, windows, lamp, candle, etc.), which, shaping the ghosts' trajectory, present the space of the house as a vertically oriented and concentric entity, evoking the concepts of VERTICALITY (Bachelard 1994: 17-20; Vorobyova 2012: 39-44) and CENTRALITY. At that, it remains an imagistic whole, provoking ideas and reveries in those who dwell here now or plunge in their memories of staying there long time ago, realising in "the deepest wells" of secret dreams and reminiscences (from the deepest wells of silence the wood pigeon drew its bubble of sound) rooted in the layers of pramemory, their belonging to "this original warmth, [...] this well-tempered matter of the material paradise" (Bachelard 1994: 8), which in the story stands out as a unity of light and love. 
Such primordial warmth, generated by light, is associated in Woolf's story, primarily, with the light of a candle (The candle burns stiff and still), the beam of a lamp (the beam I thought always burnt behind the glass; the beam of the lamp falls straight from the window; their silver lamp), which is the eye of the house, "open to night" as "through its light alone, the house becomes human. It sees like a man" (Ibid.: 35). The lamp as "the symbol of prolonged waiting" (Ibid.: 34) implies a solitary tremulous human soul as well as a fleeting nature of life, so easy to extinguish. The warmth of soul is linked to the light of the lantern (His hands shield the lantern) and the light of humaneness, which gives the others the rationality of perception as well as the realisation of what the world is and what we in this world are (their light lifts the lids upon my eyes). It differs from the cool and sometimes scary moonlight that correlates with nasty weather, worry, and timelessness - Moonbeams splash and spill wildly in the rain. [...] Wild beams of moonlight cross both floor and wall, and, meeting, stain the faces bent (Woolf 1989: 4-5). Addressing Bachelard again and again helps lift another ambiguity in Woolf's story. It is a locative ambiguity, connected with the interpretation of the preposition "behind" in the phrase "behind the glass", meaning either outside or inside the house. Bachelard's interpretation of Rimbaud's poetry, which Woolf's shorter fiction seems to be consonant with, points to the latter choice: "in the kingdom of the imagination, it [the lamp] is never lighted out-of-doors, but is enclosed light, which can only filter to the outside" (1994: 34). And it has its explanation: "All that glows sees" (Ibid.).

Quite characteristic is that, both according to Bachelard and Woolf, human beings, consciously or subconsciously, disregarding being cut off their home while exposed to external hostilities of people and the world, ousted from or devoid of their dwelling, should keep the benefits of their values deep inside, because it is "within the being, in the being of within, an enveloping warmth welcomes being" (Bachelard 1994: 7), cf., Death was the glass; death was between us; coning to the woman first, hundreds of years ago, leaving the house, sealing all the windows; the rooms were darkened. He left it, he left her, went North, went East, saw the stars turned in the Southern sky; 
sought the house; found it dropped beneath the Downs. [...] / 'Long years-' he sighs. 'Again you found me.' 'Here, 'she murmurs, '[...] Here we left our treasure-' '[...] The light in the heart' (Woolf 1989: 122-123).

Basically, an incomplete disambiguation in the story's finale can be also accounted for referring to Bachelard, who claimed that "all we communicate to others is an orientation towards what is secret without ever being able to tell the secret objectively" (1994: 13). The aura of mysteriousness is heightened in the story by a number of local background ornithological symbols, such as thrush and pigeon. "The shadow of a thrush", which crossed the carpet at the moment of the heroine's greatest confusion and doubt as well as those of the ghosts as her immaterial facet ('What did I come in here for? What did I want to find?' My hands were empty.... My hands were empty), echoes with the presence of devil the tempter, who while tempting St. Benedict appeared in front of him as a thrush. In a more general sense, the thrush symbol means engaging "in thoughtful meditation to sort out anything going on in your mind" (Wood thrush, s.a.). The double mention of wood pigeons - only the wood pigeons bubbling with content ... from the deepest wells of silence the wood pigeon drew its bubble of sound - evokes rather a mythological symbolism where a pigeon is regarded as a symbol of Venice, thus of love, and "the kindred virtues of gentleness, innocence, timidity, and peace" (Ferber 1999: 61), being at the same time a protector and comforter.

Such interpretation of A haunted house - a short story, which Woolf considered to be too sentimental (1982: 31), while Gavins called "cognitively challenging" (2003: 129), - is to an extent a collective effort. My interpretation of this story has been quite a few times verified in front of different audiences. And while its initial and final parts have in principle remained the unchanged, though somewhat modified and updated, the two fragments of analysis that follow were added thanks to the observations of my colleague $^{11}$, Yelena Tikhomirova (s.a.), concerning two complementary motifs incorporated into the master-story, i.e. narrating love as a most precious treasure and narrating epiphany as a manifestation of a supernatural force, a sudden insight, "a 
special spiritual experience, artistically depicted" (Халтрин-Халтурина 2009: 3) in the story, as well as the protagonist's liminal state.

\subsection{Disentangling predominant narrative strategies}

The technique of disentanglement, suggested by Barthes (1977: 147), is applied here to two narrative phenomena: narrative strategies and narrative stances of the characters and the narrator, which jointly shape a three-dimensional trajectory of the search for values. This latter motif creates the background for the eternal drama of two loving hearts, parted by death and still united by the happiness they had enjoyed here, in the house, which once contained their immeasurable feelings, further fossilised as their buried treasure.

Without going into detail concerning all manifestations of narrative strategies, let us dwell upon those that are related to the pivotal motif of the story, that of love as an eternal value. The problems that two loving people, the characters of A haunted house (where the protagonist combines the roles of the narrator, focaliser, and a character, while his / her lover remains virtual, implied as such by default), face reflect their uncertainty of whether they are truly happy, and if yes, then what the source of their happiness is. Shattering their doubts and finding truth require the identification of this source, the process of which is achieved here due to narrating stories of love, search for values, and getting an insight. Disentangling the narrative strategies follows here the algorithm of revealing the narrative distancing, suggested by Tikhomirova (s.a), with my modifications:

- distancing (Barthes 1977: 145) from one's love, which presupposes the emergence of an interested observer/s: here a couple of ghosts, whose mission is if not a discovery of the source of love as a true value then at least lightening the path to such a source; 
- $\quad$ estrangement from one's doubts by way of their metaphorisation: here the ghosts' search for the treasure, which metaphorically represents mutual love;

- $\quad$ further metaphorisation of love: the key metaphors based on comparing love to light in their cycling recurrence;

- $\quad$ locating love: the house (through zooming in from a human body to its partthe heart that beats) as a place where the treasure is safe;

- recognising love: by way of epiphany as a synthesis of all metaphorical facets of love, through the insight that becomes the dominant narrative focus.

This thematic line of distancing is related to searching for values as a motif, which repeats itself in quite a few Woolf's short stories (e.g., Monday or Tuesday, A simple melody, etc.). The stages of its unfolding, marked by external forces (as a virtual manifestation of the narrator ${ }^{12}$ ) that intrude, can be defined as follows:

- $\quad$ the movement of the apparitions, both estranged and involved, along horizontal and vertical labyrinths in their search of the treasure: the ghostly couple that quietly move around the house, from room to room, from one floor to another, opening the doors, looking around the corners, going down into the garden - as if imitating the liminal narrator's flight of fantasy;

- $\quad$ putting forth and verifying the hypothesis of where the lost treasure might be located: the imaginary dialogue of the ghosts as treasure-hunters against the background of the liminal narrator's virtual comments that reflect the dynamics of their assumptions and answers;

- $\quad$ plunging into the memories about the lost treasure: nasty weather and darkness as memory triggers of sad events, along with the flashes of light as flashes of hope; 
- $\quad$ getting deep into the reminiscences about the lost joy and its recovery: the ghosts' regaining their physical and spiritual closeness during their joint search for values intended for those who do not realise their significance;

- lightening the path to the treasure as the realisation of true values: the ghosts turning into love-keepers while approaching those sleeping in the house with the lantern, the light of which awakens the protagonist and fosters his / her insight.

Another thematic line of A haunted house as a story of epiphany / insight focuses upon the "moments of sharpened vision", "moments of being", the description of which is used as a narrative technique to mime a mental breakthrough - a realisation of an idea a person has reflected upon for a long time (Халтрин-Халтурина 2009: 4). Here, against the background of the joint sensory, kinetic, and emotional accretion, the internal and external narrative foci get fused ${ }^{13}$, mimicking the insight as a process and result stimulated as if from inside by the protagonist / narrator's intellectual and emotional uncertainty, as well as from the outside, as a result of striving to harmonise the present and the past, the current state of affairs and the memories that are gone. The unfolding of this thematic line includes:

- $\quad$ deep immersion into oneiric observations, or "a dream within a dream", in Poe's parlance (2017), of the treasure-hunters' (imaginary?) movement, which reminds of one's sleep slow phase as verbally construing a fragment of experience ${ }^{13}$ (Амодт \& Вонг 2009: 328): an interested observer's following the ghosts' actions, which transforms into the anxious wish to discover their intentions;

- $\quad$ interiorisation of handicaps and wrong versions on the ghosts' way to finding the treasure: empathising with those sent to enlighten and a gradual crystallisation of one's wish to join them in their search; 
- the dynamics of disappointment and hope in the treasure search: the growing feeling of obstacles that are hard to overcome together with the realisation of a true chance to eventual solve the problem;

- changes in sensory perception under the influence of favourable / unfavourable dynamics of internal and external forces: the hidden growth of the characters' intellectual and emotional strength against the background of changes in nature, which reminds of bringing together fragments of one's dreams;

- the wave-like accretion of the light energy as an insight trigger: the emergence of insight as a full-fledged creative intellectual and emotional breakthrough.

Woolf describes the process of reaching insight with a high degree of scientific precision $^{14}$ with regard to human brain activity as a constant adaptation of older systems to new objectives (see Амодт \& Вонг 2009: 59), while artistically deconstructing this process. Such adaptation is marked by the character's emotional reactions ( $I$ cry), necessary to take an appropriate decision in an ambiguous or uncertain situation (Ibid.: 193) after acquiring the threshold scope of data (Ibid.: 253).

In accordance with the current vision of creative processes where the insight belongs, each creative act starts with defining a problem, the emergence of which is accompanied by uncertainty and disappointment, the feeling of a dead end, an impasse, a mental block, frustration, which are caused by the impossibility of the prompt solution of the problem. And when one is on the verge of quitting the search, the answer dawns on you, spontaneously, as a shock, exactly at the least expected moment; it comes in its fullness, evoking the feeling of certainty in the correctness of choice (Lehrer 2012: 6-8). Experimental research of American neurobiologists and psychologists, Beeman and Kounios in particular, who, according to Lehrer, a wellknown populariser of science, managed "to deconstruct the epiphany" (Ibid.: 16), prove that insight emerges due to the activation of the right hemisphere of the human brain, which is responsible for identifying or establishing fine-tuned associative connections 
between the things or phenomena, which at first sight seem to lack any connections (Ibid.: 9). Everything that leads to insight takes place subconsciously (Ibid.: 13), when the brain seems to prepare the ground for insight: the process starts with an intensive search for answers during the left-hemispheric activity, which at a certain stage faces a painful dead-end phase of creativity. It becomes a signal of the necessity to change a searching strategy towards involving a less familiar set of associations, selecting a new, fresh angle of vision, which is a responsibility of the right hemisphere. "The suddenness of the insight is preceded by an equally sudden burst of brain activity" (Ibid.: 17), related to "a spike of gamma-wave rhythm, which is the highest electrical frequency generated by the brain" (Ibid.), while creating in such a way a neural analogue of insight.

Interestingly, "the difficulty of the task accelerates the insight process. [...] as the imagination is unleashed by constraints" (Lehrer 2012: 23). At the same time, a creative insight is predetermined by the preceding relaxation of the brain activity, which is grounded in the quiet rhythm of alpha waves that emerges when the whole body is relaxed, alongside the predominance of high, positive spirits, during the morning awakening or when a person is half asleep. In such a case, visual perception is limited, and the attention focus seems to be oriented inside. In fact, it happens when a person is in a naturally (as the protagonist of the story) or artificially caused altered state of consciousness (Ibid.: 30-34) and when "instead of responding to the outside world, the brain starts to explore its inner database" (Ibid.: 46).

Coming back to the disambiguation of the short story, one might presume that superimposition of the three motifs, those of love, search for values, and insight, as well as of various thematic lines in the depiction of the house space, heighten the impression of enigmaticity, and ambiguity, which, through the interface of bodily and artefactual dimensions, reveals the mystery of the interaction between living and dead souls, in the house that stays alive only if it contains and preserves love. 


\subsection{Conceptualising the characters' stances}

The counterpoint motif, which highlights in the short story the key concept of LOVE, is linked to the double gestalt LIFE / DEATH concept that underlies liminality as a dynamic narrative stance, fragmented through its various projections onto different liminal zones related to other complementary concepts. Such zones in the story under analysis (see Tikhomirova, s.a) are:

- LIFE / DEATH (the ghosts as liminal entities that are doomed to eternal sufferings bring enlightenment to those alive; the liminal zone: being on the borderline of the worlds of living and dead, of the infernal and sacred);

- $\quad$ SLEEP / AWAKENING (a couple of lovers, including the liminal narrator as a dreamer, a doppelganger of our personality, chiaroscuro of our thinking essence (see Bachelard 1988: 3); the liminal zone: being in between sleep and awakening, characterised by the fusion of imagination and memory (Ibid.: 10);

- $\quad$ HOUSE / GARDEN (inner and outer spaces; the liminal zone: being behind the window pane, from both sides);

- $\quad$ AN OPEN BOOK / A FALLEN BOOK (a virtual world of fantasy; the liminal zone: being immersed in reading and getting out of this state);

- $\quad$ AN OPEN SPACE / A CLOSED SPACE (internal and external spaces that "the dialectics of here and there" (Bachelard 1994: 212); the liminal zone: opening / shutting the doors as one of "primal images, the very origin of a daydream that accumulates desires and temptations" for "the door is an entire cosmos of the Half-open" (Ibid.: 222), staying behind the door from both sides);

- $\quad$ EMPTINESS / FULLNESS (empty or populated containers - the house, garden, hands, soul / heart; the liminal zone: devastation or restoration);

- $\quad$ LIGHT / DARKNESS (the present / past; the liminal zone: a sunbeam or a moonbeam, a glimmering flame of a candle as tools of breaking darkness);

- $\quad$ A VIEW FROM THE OUTSIDE / FROM INSIDE (being outside or inside the space of the human body; the liminal zone: the consciousness in reveries - "the dreaming consciousness" (Ibid.: xx). 
The peculiar feature of this short story is that the above liminal zones classified with regard to a set of semantic oppositions (sleep :: being awake, light :: darkness, the world of living :: the world of dead, etc.), regularly intersect, practically in every small textual fragment or even within a sentence, starting with the medias res of the story, e.g.,

- Whatever hour you woke there was a door shutting (3) - awakening while the closed space of the room is being opened;

- From room to room they went, hand in hand, lifting here, opening there, making sure - a ghostly couple (3) - transition of the ghosts as those dead in the world of living from one space to another, while the local physical space is being filled in ("hand in hand" instead of the protagonist's empty hands - My hands were empty);

- The candle burns stiff and still. Wandering through the house, opening the windows, whispering not to wake us, the ghostly couple seek their joy (4) - a similarity between a candle in the night and a soul in reverie (Bachelard 1988), against the background of trespassing the borders between the inner and the outer spaces, with the world of dead intruding into the world of living.

This list of illustrations can be further continued due to the recurrence of multiple liminal zone intersections and superimpositions, characteristic of this story. Such intersections give rise to the so called crossliminal metaphors (Tikhomirova 2015: 549) (DEATH IS GLASS, LOVE IS REINCARNATION), when the conceptual referent and the conceptual correlate belong to different overlapping liminal zones. They do not only become the source of ambiguities with a varying degree of opacity but function as a means of creating semantic tension, which generates the aha-effect. Here also belong cases of crossliminal oxymorons (DEATH IS LIFE), thus testifying to the transcendental nature of true live, its being beyond the control of time as love outlives death in the coordinates of eternity as the time lamniscate.

It is at this point, according to the philological circle canon (Spitzer 1948), the interpreter ought to go back and cover the whole way from identifying ambiguity sites to disentangling narrative strategies and tactics again, from another angle, in terms of 
other key metaphor linked to the concept of LIGHT, i.e. EPIPHANY / INSIGHT IS LIGHT.

The phenomenon of insight, including a literary one, alongside those of imagination and creativity, has recently caused a true multidisciplinary research boom. Woolf as well as other modernist writers, primarily Proust, whom Lehrer for every good reason calls a neuroscientist (2007), happened to foresee quite a few scientific discoveries and social phenomena of today. A haunted house contains valuable assumptions and predictions concerning the emergence, accumulation, and the final outburst of insight. Though Woolf makes an emphasis upon its connection with the flashes of light (e.g., spread about the floor, hung upon the walls, pendant from the ceiling - what? ... A moment later the light had faded. ... the trees spun darkness for a wandering beam of sun. ... Moonbeams splash and spill wildly in the rain. ... Wild beams of moonlight cross both floor and walls), abrupt movements (The shadow of a thrush crossed the carpet; ... Trees stoop and bend this way and that), and sharp sounds that intermingle with a sudden silence (The pulse stopped short. Oh, was that the buried treasure? ... The wind roars up the avenue.... I cry), resulting in the final catharsis of recognition (Waking, I cry 'Oh, is this your buried treasure? The light in the heart'), her artistic construal of insight at its various stages is grounded in rhythm and kumatoid, i.e. wavelike, dynamics of the narrative, which give way to the emotional crescendo of the ahaeffect.

The background for the aha-effect is not confined to the sinusoid of rhythm that is manifested through the sound imagery inscribed into the verbal texture, which imitates the heartbeat, shaping the would-be cardiogram of the text (Fig. 4), e.g., the pulse of the house beat softly $\rightarrow$ the pulse stopped short $\rightarrow$ the pulse of the house beat gladly $\rightarrow$ gently knocking like the pulse of a heart $\rightarrow$ the heart of the house beats proudly $\rightarrow$ the pulse of the house beats wildly $\rightarrow$ cry... (see also Воробьёва 2004: 54). 

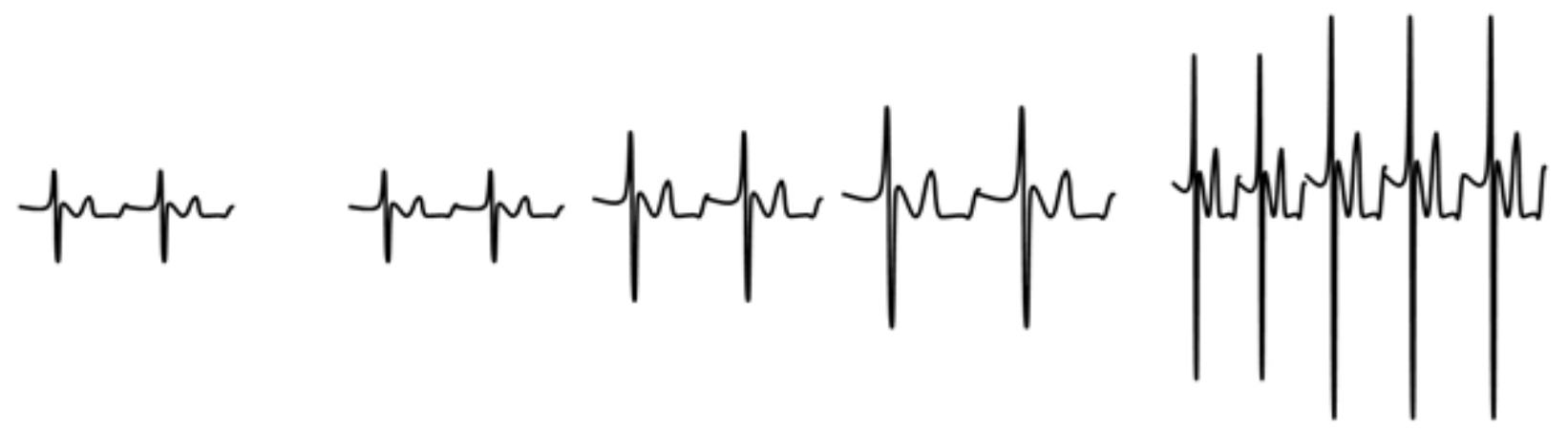

Figure 4. Textual cardiogram

This rhythmical pattern is heightened by the broken rhythm of elliptical clauses and gerundial constructions (the house all empty, the doors standing open, only the wood pigeons bubbling with content), participial (leaving the house, sealing all the windows) and verbal (He left it, left her, went North, went East) repetitions, inversions with a hidden visualisation of their vector and manner of movement (from room to room they went ... And so down again ... Nearer they come ... Long they pause).

All these and other miming techniques involve various manifestations of imagic and diagrammatic iconicity (Fischer \& Nänny 1999: xxi-xxiv) of lexico-semantic, phonosemantic, syntactic, and compositional nature. A closer look at the correlation of iconicity and literary text disambiguation is offered in the section below.

\subsection{Dismantling the verbal layers of literary texture}

This stage of analysis, which might be called a microcorpus, or nanocorpus one, because it relies upon singling out and juxtaposing heterogeneous groups of words (Balossi 2014: 3-4) to be further computed, is aimed to disentangle the "web of words" that constitutes the texture of the short story. This multidimensional network generates semantic and structural fluctuations resulting from numerous isotopies and configurations of thematically bound lexical units, accompanied by syntactic chains that create rhythm, as well as instances of phonosemantic, prosodic, and syntactic iconicity that trigger the readers' emotional response. Such fluctuations involve verbal imagery and symbolism, textual phonosemantics, its syntactical, architectonic, and 
compositional rhythm, associative chains of words, etc., creating in-built sensory iconic images and diagrams (He left it, left her, went North, went East, etc.) - visual (the light has faded), acoustic (the wind roars up the avenue), tactile (Kisses without number), and kinaesthetic (from room to room they went; nearer they come), supported by phonographemic iconicity (wandering through the house, opening the windows, whispering not to wake us; splash and spill, stiff and still). The impact of such sensory patterns is predominantly subliminal, being caused by the emotionally relevant oscillations generated by the changing intensity of textual tension.

The lexical stratum of the story's texture in all of its ten paragraphs can be divided into three thematic groups, which are associated with three subworlds of the textual universe - the world of the house, the world of the outside, and the world of the human body. Such a division is determined by the cosmogonist interaction of the three respective elements, defined by Deleuze and Guattari (1994: 178-180) in the following way:

...flesh of the world and flesh of the body that are exchanged as correlates, ideal coincidence. [...] Perhaps it would be an interference or chaos, were there not a second element to make the flesh hold fast. Flesh is only the thermometer of a becoming. The flesh is too tender. The second element is not so much bone or skeletal structure as house or framework. The body blossoms in the house [...]. The third element is the universe, the cosmos. Not only does the open house communicate with the landscape, through a window or a mirror, but the most shut-up house opens onto a universe.

The density of the thematic lexis in different parts of the text varies (see Table 2), which is visualised in the diagram (see Fig. 6). The latter testifies to three indicates culmination points that might be singled out in the short story, those related to the house, the world outside. and the human body, where the semantic splashes associated with two former spaces, gradually die out, creating a stable background for the insight as an abrupt spike in the protagonist's sensory perception, c.f., 
Table 2. Thematically bound words from the perspective of space

\begin{tabular}{|c|c|c|c|}
\hline & House & Light & Body \\
\hline 1. & door, room, room & - & hand, hand \\
\hline 2. & upstairs & garden & - \\
\hline 3. & curtain, house, doors, loft & $\begin{array}{l}\text { wood pigeons, threshing } \\
\text { machine, farm, apples, } \\
\text { garden, grass }\end{array}$ & hands \\
\hline 4. & $\begin{array}{l}\text { drawing-room, window } \\
\text { panes, glass, drawing- } \\
\text { room, door, floor, walls, } \\
\text { ceiling, carpet, house, } \\
\text { room }\end{array}$ & $\begin{array}{l}\text { apples, roses, leaves, } \\
\text { apple, wood pigeon }\end{array}$ & hands, pulse, pulse \\
\hline 5. & $\begin{array}{c}\text { glass, glass, house, } \\
\text { windows, rooms, house, } \\
\text { house }\end{array}$ & $\begin{array}{l}\text { garden, trees, beam of } \\
\text { sun, beam, North, East, } \\
\text { Southern sky, the Down }\end{array}$ & pulse \\
\hline 6. & $\begin{array}{l}\text { beam of lamp, window, } \\
\text { candle, house, windows }\end{array}$ & $\begin{array}{l}\text { wind, avenue, trees, moon } \\
\text { beams, rain }\end{array}$ & - \\
\hline 7. & doors & trees, garden & pulse, heart \\
\hline 8. & doorway, glass, lantern & wind, rain & eyes, hands, lips \\
\hline 9. & lamp, flame, slippers & wind, beam of moonlight & - \\
\hline 10. & house, loft, house & garden, aps & $\begin{array}{l}\text { heart, lids, eyes, } \\
\text { pulse, heart }\end{array}$ \\
\hline
\end{tabular}




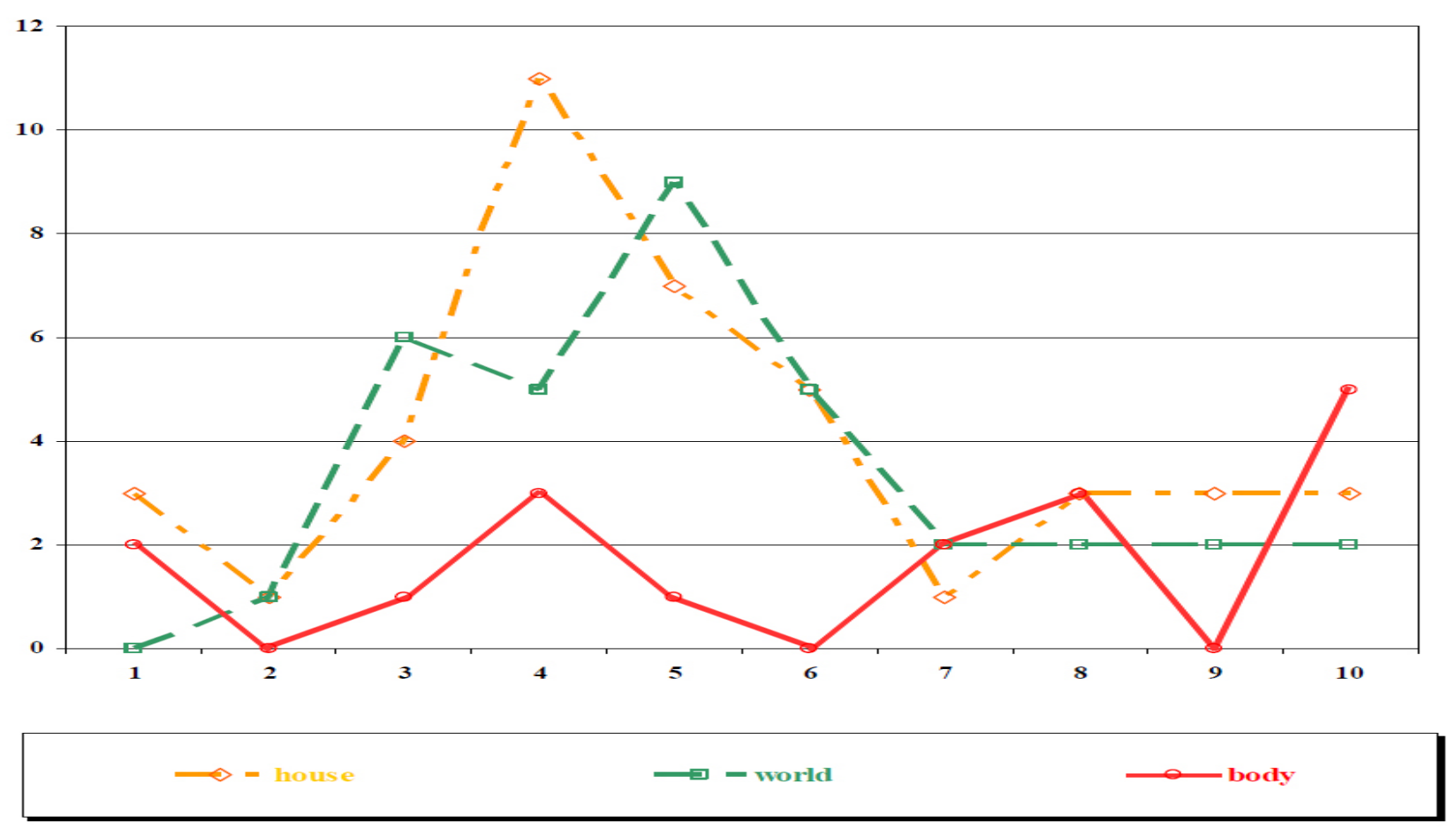

Figure 6 . The diagram of thematically bound words distribution

Another distribution of the thematically bound words is based on their reference to a sensory "melody" constituted by the significations of sound (quiet or loud), temperature (high or low), and light (mild or intense) (see Table 3).

Table 3. Thematically bound words designating sensory perception

\begin{tabular}{|c|c|c|c|c|c|c|}
\hline & \multicolumn{2}{|c|}{ Sound } & \multicolumn{2}{|c|}{ Temperature } & \multicolumn{2}{|c|}{ Light } \\
\hline & low & loud & low & high & weak & intense \\
\hline 1 & $\begin{array}{l}\text { a ghostly } \\
\text { couple }\end{array}$ & a door shutting & $\begin{array}{c}\text { a ghostly } \\
\text { couple }\end{array}$ & - & $\begin{array}{l}\text { a ghostly } \\
\text { couple }\end{array}$ & - \\
\hline 2 & $\begin{array}{l}\text { she murmured, } \\
\text { he whispered }\end{array}$ & - & - & - & - & - \\
\hline 3 & $\begin{array}{l}\text { drawing the } \\
\text { curtain, wood } \\
\text { pigeons bubb- } \\
\text { ling, hum of } \\
\text { the threshing } \\
\text { machine soun- } \\
\text { ding from the } \\
\text { farm, the } \\
\text { garden still }\end{array}$ & - & - & - & - & - \\
\hline
\end{tabular}




\begin{tabular}{|c|c|c|c|c|c|c|}
\hline & \multicolumn{2}{|c|}{ Sound } & \multicolumn{2}{|c|}{ Temperature } & \multicolumn{2}{|c|}{ Light } \\
\hline 4 & $\begin{array}{l}\text { the deepest } \\
\text { wells of silen- } \\
\text { ce, bubble of } \\
\text { sound, beat } \\
\text { softly }\end{array}$ & - & - & the beam burnt & $\begin{array}{l}\text { window panes } \\
\text { reflected } \\
\text { apples, re- } \\
\text { flected roses, } \\
\text { the shadow of } \\
\text { a thrush }\end{array}$ & $\begin{array}{l}\text { all the leaves } \\
\text { were green in } \\
\text { the glass, the } \\
\text { apple turned its } \\
\text { yellow side }\end{array}$ \\
\hline 5 & whispering & beat gladly & $\begin{array}{l}\text { cooly, death } \\
\text { was the glass }\end{array}$ & - & $\begin{array}{l}\text { the light had } \\
\text { faded, a wan- } \\
\text { dering beam of } \\
\text { sun, the rooms } \\
\text { were darkened }\end{array}$ & $\begin{array}{l}\text { the beam burnt, } \\
\text { stars turned in } \\
\text { the Southern } \\
\text { sky }\end{array}$ \\
\hline 6 & $\begin{array}{l}\text { trees bend this } \\
\text { way and that, } \\
\text { moonbeams } \\
\text { splash in the } \\
\text { rain, whisper- } \\
\text { ing, the ghostly } \\
\text { couple }\end{array}$ & the wing roars & $\begin{array}{l}\text { splash in the } \\
\text { rain, the } \\
\text { ghostly couple }\end{array}$ & $\begin{array}{l}\text { the candle } \\
\text { burns }\end{array}$ & $\begin{array}{l}\text { the ghostly } \\
\text { couple }\end{array}$ & $\begin{array}{l}\text { moonbeams } \\
\text { splash and spill } \\
\text { wildly, the } \\
\text { beam of the } \\
\text { lamp, the } \\
\text { candle burns }\end{array}$ \\
\hline 7 & $\begin{array}{l}\text { the doors go } \\
\text { shutting far in } \\
\text { the distance, } \\
\text { gently knock- } \\
\text { ing }\end{array}$ & - & $\begin{array}{l}\text { silver between } \\
\text { the trees, } \\
\text { winter snow- } \\
\text { time }\end{array}$ & summer & $\begin{array}{l}\text { silver between } \\
\text { the trees }\end{array}$ & - \\
\hline 8 & $\begin{array}{l}\text { the wind falls, } \\
\text { the rain slides } \\
\text { silver down the } \\
\text { glass, we hear } \\
\text { no steps, he } \\
\text { breathes, sound } \\
\text { asleep }\end{array}$ & - & $\begin{array}{l}\text { the rain slides } \\
\text { silver down the } \\
\text { glass }\end{array}$ & - & $\begin{array}{l}\text { the rain slides } \\
\text { silver down the } \\
\text { glass, his hands } \\
\text { shield the } \\
\text { lantern }\end{array}$ & - \\
\hline 9. & - & $\begin{array}{l}\text { the wind drives } \\
\text { straightly }\end{array}$ & $\begin{array}{l}\text { beams of } \\
\text { moonlight }\end{array}$ & the flame & silver lamp & $\begin{array}{l}\text { the flame } \\
\text { stoops slightly, } \\
\text { wild beams of } \\
\text { moonlight }\end{array}$ \\
\hline 10. & $\begin{array}{l}\text { he sighs, she } \\
\text { murmurs }\end{array}$ & $\begin{array}{l}\text { beats proudly, } \\
\text { laughing, } \\
\text { rolling apples, } \\
\text { beats wildly, I } \\
\text { cry }\end{array}$ & - & - & - & $\begin{array}{l}\text { the light lifts } \\
\text { the lids upon } \\
\text { my eyes }\end{array}$ \\
\hline & \multicolumn{2}{|c|}{ the light in the heart } & \multicolumn{2}{|c|}{ the light in the heart } & \multicolumn{2}{|c|}{ he light in the heart } \\
\hline
\end{tabular}

At this, according to Deleuze and Guattari (1994: 185-186),

There is counterpoint whenever a melody arises as a "motif" within another melody [...]. These relationships of counterpoint join planes together, form compounds of sensations and blocs, and determine becomings. Sometimes forces blend into one another in subtle transitions, decompose hardly glimpsed; and sometimes they alternate or conflict with one another. 
Such lexical density, displayed in the spectrogram below (Fig. 7), shows the prevalence of quiet subdued background, involving both sounds and silence, with the dominance of sibilants and fricatives jointly miming rustle, whisper, and murmur.

All this creates the background for relatively balanced modes of temperature and light, finally resulting in an abrupt sound splash, accompanied by the splash of intense light at the end of the short story. Due to multifarious manifestations and modes of iconicity the image of the house acquires a particular depth and dimensionality, with the effect of energy saturation in its constant dynamics.

The latter is also marked by the colour palette: along the scale from warm colours - the green colour of leaves, the yellow seduction of apples, and pallid overtones of roses at the beginning of the story - to the silver-cool colours of the moonlight that implies intuition, imagination, and illusionary nature of human existence, halfway through the story with the final return to the apple warmth in the end of the text.

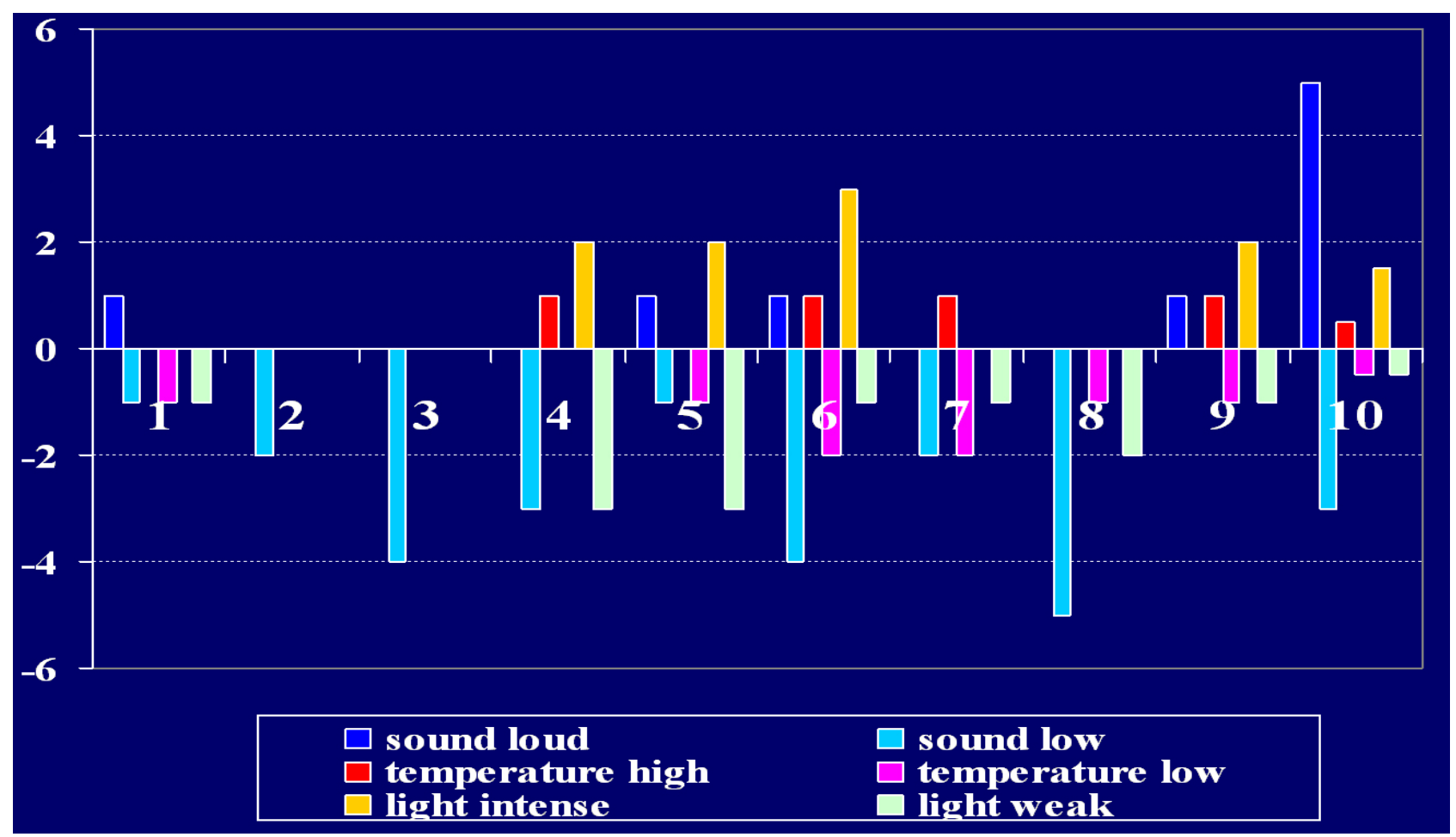

Figure 7. Spectrogram of sensory lexis 


\section{Discussion and conclusion}

The methodology of literary discourse disambiguation suggested in this paper displays quite a few features of a metamethod, which can be listed as follows:

- it combines traditional and novel techniques of analysis, bringing them to the required level of compatibility;

- it provides a methodological multidimensionality, synthesising stylistic, cognitive, narrative, and semiotic facets of literary discourse;

- it gives the algorithm of disambiguation an acceptable degree of flexibility, adapting it in the order and recurrence of its constituent stages to each concrete literary text;

- it envisages a subtler and more profound access to hidden senses elicited through disambiguation with every other stage of analysis;

- it offers ways of generalising upon local instances of disambiguation against the background of globally ambiguous literary discourse viewed in terms of vertical context and current scholarly, as well as scientific contexts.

The integrated methodology of disambiguation applied to Woolf's shorter fiction highlighted some of those facets of the writer's linguistic personality, which concern her cognitive style, manifestations of individual sensory perception with a particular sensitivity to rich colour, sound, and temperature palettes, idiosyncratic imagery and symbolism of light, motion, house, and other artefacts and natural elements. Disambiguation techniques evolved and / or upgraded in this paper reveal a particular role of the emotional accretion, along with the in-built body / mind dyad, which permeate the story under analysis, eventually lifting suspense accumulated by the end of the narrative.

\section{References}

Aamodt, S. \& Wang, S. (2009). Mysteries of our brain, or Why clever people act follishly. Moscow: ECSMO. / Amodt, S., Vong, S. Tainy nashego mozga, ili Pochemu 
umnyye lyudi delayut gluposti. Moskva: EKSMO. / Амодт С., Вонг С. Тайны нашего мозга, или Почему умные люди делают глупости. Москва: ЭКСМО.

Ambiguity and the search for meaning: English and American studies at the beginning of the $21^{\text {st }}$ century (2010). Coghen, M., Mazur, Z. \& Piątek, B. (eds.). 1: Literature; Jodłowich, M. \& Leśniewska, Ju. (eds.). 2: Language and culture. Kraków: Jagiellonian University Press.

Ambiguous discourse: Feminist narratology and British women writers (1996). Mezei, K. (ed.). Chapel Hil-London: The University of Carolina Press.

Bachelard, G. (1988). The flame of a candle. Dallas: The Dallas Institute Publications. Bachelard, G. (1994). The poetics of space. Boston: Beacon Press.

Baldwin, D.R. (1989). Virginia Woolf: A study of the short fiction. Boston: Twayne Publishers. A division of G.K. Hall \& Co.

Balossi, Gu. (2014). A corpus linguistic approach to literary language and characterization: Virginia Woolf's The waves. Amsterdam-Philadelphia: John Benjamins.

Barthes, R. (1977). The death of the author. In Barthes, R. Image. Music. Text. Essays sel. and transl. by S. Heath. London: Fontana Press, an imprint of HarperCollins Publishers, p. 142-148.

Beauty and brain: Biological aspects of aesthetics. (1988). Rentschler, I., Herzberger, B. \& Epstein, D. (eds.). Basel, etc.: Birkhauser.

Belekhova, L.I. (2002). Verbal poetic image from the historical typological; perspective: A cognitive aspect (A study of American poetry). Kherson: Ailant. I Byelyexova, L.I. Slovesnyj poetychnyj obraz $v$ istoryko-typolohichnij perspectyvi: kohnityvnyj aspect (na materiali amerykans'koyi poeziiy). Xerson: Ajlant. I Бєлєхова Л.І. Словесний поетичний образ в історико-типологічній перспективі: лінгвокогнітивний аспект (на матеріалі американської поезії). Херсон: Айлант. Burke, M. (2001). Iconicity and literary emotion. In European journal of English studies, 5(1), p. 31-46.

Cambridge international dictionary of English (1995). Cambridge: Cambridge University Press. 
Chafe, W. (2010). Literature as a window to the mind. In Acta linguistica hafniensia: International journal of linguistics, 42(S1), p. 51-63. Jelsbak, T. \& Zeuthen, N. (eds.). Special Issue: Travaux de Cercle Linquistique de Copenhague, XXXIV: Linguistics and Poetics. Proceedings of the International Conference in Copenhagen, 24-25 January, 2008.

Ciugureanu, A. (2001). The ideogram as an iconic dimension in Ezra Pound's early Cantos. In European journal of English studies, 5(1), p. 47-58.

Darian, S. (2001). Technique in creative writing, s.l.

Deleuze, G. \& Guattari, F. (1994). What is philosophy? New York: Columbia University Press.

De Mey, M. (2006). Mastering ambiguity. In The artful mind. Cognitive science and the riddle of human creativity. Turner, M. (ed.). Oxford, etc.: Oxford University Press, p. 271-304.

Doležel, L. (1998). Heterocosmica: Fiction and possible worlds. Baltimore-London: The John Hopkins University Press.

Eco, U. (1990). Small worlds. In Eco, U. The limits of interpretation. BloomingtonIndianapolis: Indiana University Press, p. 64-82.

Empson, W. (2001). Seven types of ambiguity. $15^{\text {th }}$ ed. New York: New Directions.

Everdell, W.R. (1997). The first moderns: Profiles in the origins of twentieth-century thought. Chicago-London: The University of Chicago Press.

Fauconnier, G. (1994). Mental spaces: Aspects of meaning construction in natural language. Cambridge, etc.: Cambridge University Press.

Ferber, M. (1999). The dictionary of literary symbols. Cambridge: Cambridge University Press.

Fischer, O. \& Nänny, M. (1999). Introduction: Iconicity as a creative force in language use. In Form miming meaning. Iconicity in language and literature. Nänny, M. \& Fischer, O. (eds.). Amsterdam-Philadelphia: John Benjamins, p. xv-xxxvi.

Freeman, M.H. (2014). Cognitive poetics. In The Routledge handbook of stylistics. Burke, M. (ed.). London-New York: Routledge, p. 313-328. 
Freeman, M.H. (2005). Poetry as power: The dynamics of cognitive poetics as a scientific and literary paradigm. In Cognition and literary interpretation in practice. Veivo, H., Pettersson, B. \& Polvinen, M. (eds.). Helsinki: Helsinki University Press, p. 31-57.

Gavins, J. (2007). Text world theory. An introduction. Edinburgh: Edinburgh University Press.

Gavins, J. (2003). 'Too much blague?' An exploration of the text worlds of Donald Barthelme's Snow White. In Cognitive poetics in practice. Gavins, J. \& Steen, G. (eds.). London-New York: Routledge, p. 129-144.

Gibbon, D. (2010). The ambiguity of 'ambiguity': Beauty, power, and understanding. In Ambiguity and the search for meaning: English and American studies at the beginning of the $21^{\text {st }}$ century. Jodłowich, M. \& Leśniewska, Ju. (eds.). 2: Language and culture. Kraków: Jagiellonian University Press, p. 33-51.

Grzesiak, H. Helle Cook - notion of home. In Brisbane artguide, p. 1-20. Available at: http://bneart.com/writing/

Gyubbenet, I.V. (2010). Fundamentals of literary text philological interpretation. $2^{\text {nd }}$ ed., enl. Moscow: "LIBROCOM" Publishhing house. / Gyubbenet, I.V. Osnovy filologicheskoj interpretatsii literaturno-xudozhestvennogo teksta. Moskva: Knizhnyj dom "LIBROKOM". / Гюббенет И.В. Основы филологической интерпретации литературно-художественного текста. Изд. 2-е, доп. Москва: Книжный дом "ЛИБРОКОМ".

Hall, G. (2014). Pedagogical stylistics. In The Routledge handbook of stylistics. Burke, M. (ed.). London-New York: Routledge, p. 239-252.

Haltrin-Khalturina, Ye. (s.a.): From romantic "manifestations of imagination" to modernist "epiphanies": A case of continuity. / Haltrin-Xalturina, Ye. Ot romanticheskix "vspyshek voobrazheniya" $k$ modernistskim "yepifaniyam": preyemstvennaya svyaz'. / Халтрин-Халтурина Е.В. От романтических "вспышек воображения" к модернистским "эпифаниям": преемственная связь. Available at: http://ekhalt.freeshell.org/Articles/epiphanies.htm 
Haltrin-Khalturina, Ye.V. (2009). Poetics of blessed visions in English romanticism: Romantic judgements on imagination and literary praxis. A.M. Gorkii Institute of World Literature of RAS. Moscow: Nauka. / Haltrin-Xalturina, E.V. Poetika "ozarenij" $v$ literature anglijskogo romantizma: romanticheskiye suzhdeniya o voobrazhenii i xudozhestvennaya praktika. Institut mirovoj literatury im. A.M. Gor'kogo RAN. Moskva: Nauka. / Халтрин-Халтурина Е.В. Поэтика "озарений" в литературе английского романтизма: Романтические суждения о воображении и художественной практике. Институт мировой литературы им. А.М. Горького РАН. Москва: Наука.

Hirsch, E.D., Jr., Kett, J.E. \& Trefill, J. (1993). The dictionary of cultural literacy. $2^{\text {nd }}$ ed., rev. and updat. Boston-New York: Houghton Mifflin.

Jodłowich, M. (2010). Disambiguation and context. In Ambiguity and the search for meaning: English and American studies at the beginning of the $21^{\text {st }}$ century. Jodłowich, M. \& Leśniewska, Ju. (eds.) 2: Language and culture. Kraków: Jagiellonian University Press, p. 75-89.

Kahanovs'ka, O.M. (2002). Text concepts of literary prose (A study of the mid-20 $0^{\text {th }}$ century French novels). Kyiv: KNLU Publishing centre. / Kahanovs'ka, O.M. Tekstovi kontsepty xudozhnyoyi prozy (na materiali frantsuz'koyi romanistyky seredyny 20 storichchya). Kyyiv: Vydavnychyi tzsentr KNLU / Кагановська О.M. Текстовi концепти художньої прози (на матеріалі французької романістики середини XX сторіччя). Київ: Видавничий центр КНЛУ.

Kolyesnik, D.M. (1996). Conceptual space of the authorial metaphor in A. Murdock's literary works. Thesis for the Candidate Degree in Philology, Speciality 10.02.04 Germanic Languages. The Bogdan Xmelnytskyi State University of Cherkassy, Cherkassy / Kolyesnik, D.M. Kontseptual'noye prostranstvo avtorskoj metafory $v$ tvorchestve A. Merdok. Dissertatsiya na soiskaniye nauchnoj stepeni kandidata filologicheskix nauk po spetsial'nosti 10.02.04 - germanskiye yazyki. Cherkasskij gosudarstvennyj universitet im. Bogdana Xmel'nitskogo. Cherkassy / Колесник Д.М. Кониептуальное пространство авторской метафоры в творчестве А. Мердок. Диссертация на соискание научной степени кандилата филологических наук по 481 
специальности 10.02.04 - германские языки. Черкасский государственный университет им. Богдана Хмельницкого. Черкассы.

Lehrer, J. (2012). Imagine: How creative mind works. Edinburgh-London: Canongate. Lehrer, J. (2007). Proust was a neuroscientist. Edinburgh, etc.: Canongate.

Lotman, Yu.M. (1982). The text and the structure of its audience. In New literary history, Problems of literary theory, 14(1), p. 81-87.

Mahlberg, M. (2005). English general nouns: A corpus theoretical approach. Amsterdam-Philadelphia: John Benjamins.

Mahlberg, M. (2013). Corpus stylistics and Dickens's fiction. London-New York: Routledge.

Mezei, K. (1996). Introduction. Contextuaizing feminist narratology. In Ambiguous discourse: Feminist narratology and British women writers. Mezei, K. (ed.). Chapel Hill-London: The University of Carolina Press, p. 1-20.

Miller, N. Hauntology and history in Jacques Derrida's Spectres of Marx. Available at: https://www.nodo50.org/cubasigloXXI/taller/miller_100304.pdf

Molchanova, G.G. (2007). English as a non-native language: Text, style, culture, communication. Moscow: OLMA Media Group. / Molchanova, G.G. Angliyskiy kak nerodnoj: tekst, stil', kul'tura, kommunikatsiya. Moskva: OLMA Media Grupp. I Молчанова, Г.Г. Английский как неродной: текст, стиль, культура, коммуникация. Москва: ОЛМА Медиа Групп.

Nikonova, V.H. (2007). Tragedy model of the world in Shakespear's poetics. Dnipropetrovs'k: DUEL Publishing House. / Nikonova, V.H. Trahedijna kartyna svitu $v$ poetytsi Shekspira. Dnipropetrovs'k: Vydavnytstvo DUEP. / Ніконова В.Г. Трагедійна картина світу в поетиці Шекспіра. Дніпропетровськ: Видавницво ДУЕП.

Nöth, W. (1990). Handbook of semiotics. Bloomington-Indianapolis: Indiana University Press.

Pedagogical stylistics: Current trends in language, literature and ELT (2012). Burke, M., Csábi, S., Week, L. \& Zerkowitz, Ju. (eds.). London-New York: Continuum. 
Poe, E.A. (2017). A dream within a dream. In Poetry foundation. Poetry magazine. Available at: https://www.poetryfoundation.org/poems-and-poets/poems/detail/52829 Ratiani, I. (2007). Theory of liminality. In Litinfo. Georgian electronic journal of literature, 1 (1). Available at: http://www.litinfo.ge/issue-1/ratianiirma.htm Rimmon, Sh. (1977). The concept of ambiguity - the example of James. Chicago: The University of Chicago Press.

Ryan, M.-L. (2008). Possible-worlds theory. In Routledge encyclopedia of narrative theory. Herman, D., Jahn, M. \& Ryan, M.-L. (eds.). London-New York: Routledge, p. 446-450.

Scholes, R. (1982). Semiotics and interpretation. New Haven-London: Yale University Press.

Semino, E. (2006). Blending and characters' mental functioning in Virginia Woolf's 'Lappin and Lapinova'. In Language and literature, 15 (1), p. 55-72.

Semino, E. (1997). Language and world creation in poems and other texts. LondonNew York: Longman.

Shaffer, E. (2010). Seven times seven types of ambiguity: William Empson and twentieth-century criticism. In Ambiguity and the search for meaning: English and American studies at the beginning of the $21^{\text {st }}$ century. Coghen, M., Mazur, Z. \& Piątek, B. (eds.). 1: Literature. Kraków: Jagiellonian University Press, p. 11-23.

Spitzer, L. (1948). Linguistics and literary history. Essays in stylistics. Princeton: Princeton University Press.

Stepanov, Yu.S. (1965). French stylistics. Moscow: "Higher school" Publishing house. / Stepanov, Yu.S. Frantsuzskaya stilistika. Moskva: Izdatel'stvo "Vysshaya shkola". I Степанов Ю.С. Франиузская стилистика. Москва: Изд-во "Высшая школа".

Stepanov, Yu.S. (2007). Concepts. A thin film of civilisation. Moscow: Languages of Russian culture. / Stepanov, Yu.S. Kontsepty. Tonkaya plyonka tsivilizatsii. Moskva: Yazyki russkoj kul'tury. / Степанов Ю.С. Концеепты. Тонкая плёнка ц̧ивилизации. Москва: Языки русской культуры.

Stockwell, P. (2002). Cognitive poetics: An introduction. London: Routledge. 
Tikhomirova, Ye. (s.a.) Looking at 'A haunted house' by Virginia Woolf through a cognitive glass. Unpublished essay.

Tikhomirova, Ye.V. (2015). Transcultural image of the Other world in Charles de Lint's Newford series. In Contemporary literary studies, 12. Kyiv: KNLU Publishing House, p. 541-550. / Tixomirova, Ye.V. Transkulturnyi obraz Inogo mira v "Niyufordskom tsyklye" Charl'za de Linta. In Suchasni literaturoznavchi studiyi, 12. Kyyiv: Vydavnychyi tzsentr KNLU, s. 541-550. / Тихомирова Е.В. Транскультурный образ Иного мира в "Ньюпортском цикле" Чарльза де Линта. In Сучасні літературознавчі студї, 12. Київ: Видавничий центр КНЛУ, с. 541550.

The Holy Bible. King James version. (1991). New York: Ivy Books.

Toolan, M. (2009). Narrative progression in the short story. A corpus stylistic approach. Amsterdam-Philadelphia: John Benjamins.

Tsur, R. (1992). Toward a theory of cognitive poetics. Amsterdam, etc.: Elsevier Science.

Turner, F. \& Pöppel, E. (1988). Metered poetry, the brain and time. In Beauty and brain: Biological aspects of aesthetics. Rentschler, I., Herzberger, B. \& Epstain, D. (eds.). Basel, etc.: Birkhauser, p.71-90.

Turner, M. (1996). The literary mind: The origins of thought and language. New YorkOxford: Oxford University Press.

Turner, M. \& Fauconnier, G. (2002). The way we think: Conceptual blending and the mind's hidden complexities. New York: Basic Books.

Turner, V. (1974). Liminal to liminoid, in play, flow and ritual: An essay in comparative symbology. In Rice institute pamphlet - Rice university studies, 60 (3), p. 53-92. Available at:

https://scholarship.rice.edu/bitstream/handle/1911/63159/article_RIP603_part4.pdf

Turner, V.W. (1964). Betwixt and between: The liminal period in Rites de passage. In Symposium on new approaches to the study of religion. Proceedings of the annual spring meeting of the American ethnological society. Helm, Ju. (ed.). Seattle: The University of Washington Press, p. 4-20. 
Vorobyova, O. (2003). Disambiguation of literary discourse: A cognitive script. In $8^{\text {th }}$ international cognitive linguistics conference: Cognitive linguistics, functionalism, discourse studies: Common ground and new directions, Logroňo, 20-25 July, 2003. Logroňo: University of La Rioja, p. 156.

Vorobyova, O. (2002). Haunted by ambiguities: Viewpoints on the point-of-view in Virginia Woolf's "A haunted house ". In IALS 2002: International association for literary semantics, $3^{\text {rd }}$ international conference, Birmingham, 7-9 April, 2002. Birmingham: Birmingham University Press.

Vorobyova, O. (2017). Virtual narrative in Virginia Wool's "A simple melody": Cognitive and semiotic implications. In Language - literature - the arts: A cognitivesemiotic interface. Chrzanowska-Kluczewska, E. \& Vorobyova, O. (eds.). Frankfurt am Main: Peter Lang, p. 95-112.

Vorobyova, O.P. (2012). Caught in the web of worlds: Postmodernist wanderings through the ASC labyrinth in Kazuo Ishiguro's The unconsoled - Philosophy, emotions, perception. In Languages, literatures and cultures in contact: English and American studies in the age of global communication: 2: Language and culture: Dąbrowska, M., Leśniewska, Ju. \& Piątek, B. (eds.). Krakow: Tertium, p. 37-56. Vorobyova, O.P. (2002a). Close reading techniques in the language-through-literature classroom: A cognitive perspective. In Proceedings of the international conference "Innovative approaches to teaching foreign languages and cultures in the new millennium". Dnipropetrovs'k: DUEL, p. 18-21. / Vorobyova, O.P. Close reading techniques in the language-through-literature classroom: A cognitive perspective. In Mizhnarodna konferentsiya "Innovatsijni pidxody do navchannya inozemnyx mov ta kul'tur u novomu tysyacholitti". Dnipropetrovs'k: DUEP, s. 18-21. / Vorobyova, O.P. Close reading techniques in the language-through-literature classroom: A cognitive perspective. In Міжнародна конференція "Інновачійні підходи до навчання іноземних мов та культур у новому тисячолітті". Дніпропетровськ: ДУЕП, c. 18-21.

Vorobyova, O.P. (1996) Linguistic signals of addressee-orientation in the source and target literary texts: A comparative study. In CLS 32. Papers from the parasession on 
theory and data in linguistics. McNair, L., Singer, K., Dobrin, L.M. \& Aucoin, M.M. (eds.). Chicago: Chicago Linguistic Society, p. 165-175.

Vorobyova, O.P. (2006). The idea of resonance in linguistic research. In Language. Man. World: Festschrift to Prof. M.P. Kocherhan's $70^{\text {th }}$ anniversary; Coll. of schol. papers. Taranenko, O.O. (ed.). Kyiv: KNLU Publishing House, p. 72-86. / Vorobyova, O.P. Ideya rezonansu v linhvistychnyx doslidzhennyax. In Mova. Lyudyna. Svit: Do 70-richchya prof. M.P. Kocherhana: Zb. nauk. statey. Taranenko, O.O. (red.). Kyyiv: Vydavnychyi tsentr KNLU, s. 72-86. / Воробйова, О.П. Ідея резонансу в лінгвістичних дослідженнях. In Мова. Людина. Світ: До 70-річчя проф. М.П. Кочергана. Зб. наук. статей. Тараненко О.О. (ред.). Київ: Видавничий центр КНЛУ, с. 72-86.

Vorobyova, O.P. (2010). Verbal holography in Virginia Woolf's landscape discourse: Modes, fractals, fusions. In Cognition, communication, discourse. Electronic Journal, Series: Philology, 1, p. 47-74. / Vorobyova, O.P. Slovesnaya golografiya v pejzazhnom diskurse Virdzhinii Vulf: modusy, fraktaly, fuzii. In Kohnitsiya, komunikatsiya, dyskurs. Elektronnyj zbirnyk naukovyx prats'. Seriya: Filolohiya, 1, s. 47-74. I Воробьёва О.П. Словесная голография в пейзажном дискурсе Вирджинии Вулф: модусы, фракталы, фузии. In Когніція, комунікайія, дискурс: Електронний збірник наукових пращь. Серія: Філологія, 1, с. 47-74. Available at: http://sites.google.com/site/cognitiondiscourse/vypusk-no1-2010

Vorobyova, O.P. (2004). Virginia Woolf from the linguistic personality perspective: A cognitive etude. In Language and transnational issues. Proceedings of the international conference. Fesenko, T.A. (ed.). Moscow-Tambov: TSU, p. 50-56. I Vorobyova, O.P. Virdzhiniya Vul'f v aspekte yazykovoj lichnosti: kognitivnyj etyud. In Yazyk i transnatsional'nyye problemy. Materialy mezhdunarodnoj konferentsii. Fesenko, T.A. (red.). Moskva-Tambov: TGU, s. 50-56. / Воробьёва О.П. Вирджиния Вульф в аспекте языковой личности: когнитивный этюд. In Язык $u$ транснациональные проблемы: Материаль Междунаодной. Конференциию Фесенко Т.А. (ред.). Москва-Тамбов: ТГУ, с. 50-56. 
Werth, P. (1999). Text worlds: Representing conceptual space in discourse. New York: Longman/Pearson Education.

West, D. (2016). Cognitive stylistics. In The Bloomsbury companion to stylistics. Sotirova, V. (ed.). London, etc.: Bloomsbury Academic; An imprint of Bloomsbury Publishing, p. 109-121.

Wood thrush animal totem symbolism. In SunSignorg. Available at: http://www.sunsigns.org/wood-thrush-animal-totem-symbolism-meanings/

Woolf, V. (1982). A writer's diary. New York: Houghton Mufflin Harcourt.

Woolf, V. (1989). The co mplete shorter fiction of Virginia Woolf. $2^{\text {nd }}$ ed. Susan Dick, S. (ed.). San Diego, etc.: A Harvest Book, Harcourt.

Zeki, S. (2006). The neurology of ambiguity. In The artful mind. Cognitive science and the riddle of human creativity. Turner, M. (ed.). Oxford, etc.: Oxford University Press, p. 243-270.

Zeki, S., Aglioti, S., McKeefry, D. \& Berlucchi G. (1999). The neurological basis of conscious color perception in a blind patient. In Proceedings of the national academy of sciences of the United States of America, 96 (24), p. 14124-14129. Available at: https://philpapers.org/rec/ZEKTNB

Zyngier, S. \& Fialho, O. (2016). Pedagogical stylistics: charting outcomes. In The Bloomsbury companion to stylistics. Sotirova, V. (ed.). London, etc.: Bloomsbury Academic; An imprint of Bloomsbury Publishing, p. 208-230.

\section{Notes:}

1. Such a didactic perspective in research is also traced in philosophical works. Thus, Deleuze and Guattari mention "a pedagogy of the concept, which would have to analyze the conditions of creation as factors of always singular moments" (1994: 12). 2. There exists an alternative interpretation of the term "ambiguity", which covers "the relation obtaining between mutual exclusives" only, but not such "cognate phenomena like "double and multiple meaning", "openness", "vagueness", "symbolism" (Rimmon 1977: xi) that are traditionally referred to as "ambivalence", a variety of ambiguity. 
3. In semiotics, ideograms, or ideographs (Nöth 2000: 254), are "those graphemes which symbolize elements of content" (Ibid.: 253). Among the rest, semioticians single out compound ideograms, i.e. "combinations of two or more characters motivating the meaning of a new concept" (Ibid.: 254) and functioning as diagrammatic icons. In poetics, ideograms are considered from a wider perspective. Similarly to characters in Chinese poetry, which "express an abstract notion by juxtaposing a number of single characters used for concrete things" (Ciugureanu 2001: 49), e.g., cherry, rose, sunset, iron-rust, flamingo for various shades of the colour "red", any other poetic (or, wider, textual) ideogram, "applied to other abstract notions (e.g., 'love', 'hatred', 'passion', 'beauty', or 'courage')", may turn into "a complex signifier [...] made up of various parts which, seen as a whole, may be read as symbolic codes, but which, seen partially or individually, may form imagic and diagrammatic icons (Ibid.), jointly designating a certain feeling, sensation, or abstract notion.

4. The idea of disentanglement proved to be extremely productive for literary text disambiguation as, according to Barthes (1977: 147), "In the multiplicity of writing, everything is to be disentangled, nothing deciphered; the structure can be followed, 'run' (like the thread of a stocking) at every point and at every level".

5. Current corpus approach, alongside its other areas, includes a rapidly developing corpus stylistics (Balossi 2014; Mahlberg 2013; Toolan 2009), which, elaborating further the methodology of corpus linguistics (Mahlberg 2005 et al.), grounded in statistical processing of massive collections of computerised texts, which does not only allow to verify research intuition as to concrete stylistic phenomena, but also reveal common stylistic trends and regularities that do not come to the surface within a limited scope of textual material.

6. "Haunted" is not only associated with a place often visited by a spirit of a dead person but also "means showing signs of suffering or severe anxiety" (Cambridge international dictionary 1995: 851).

7. The validity of such an interpretation may be linked to the assumption that "concepts are centers of vibrations, each in itself and every one in relation to all the others. This 
is why they all resonate rather than cohere or correspond with each other. There is no reason why concepts should cohere" (Deleuze \& Guattari 1994: 13).

8. The notion of epiphany, in James Joyce's terms, is understood here, in line with Haltrin-Khalturina, not as a sacred religious insight, but as secular, psychological phenomenon that envisages "a particular sharpening of feelings: a character (or a lyrical "I") no longer looks into the world with a regular "bodily eye". S/he perceives the world with her / his heart - and the world transforms in front of him" (Халтрин-Халтурина, s.a.). Such "moments of vision" reflect the character's state of mind provoked by a specific perception of the world and specific emotional; experience acquired at such "moments of psychological insight" (Ibid.).

9. The term "hauntology" (from "to haunt + ontology") interpreted as the being of spirits, or the being of ghosts, was introduced by Derrida in his Spectres de Marx to designate a paradoxical state between being and not being (Miller, s.a.). Later this term started to be used in musicology to denote a trend in music, which is characterised by ephemerality and memory phantoms.

10. The phenomenon of liminality (from Latin "limen" - "threshold") is usually associated with the names van Gennep and Turner (1964; 1974), the latter defining it as a marginal, transitional, in-between, "interstructural situation" (1964: 4), which "captures inbetween situations and conditions characterised by the dislocation of established structures, the reversal of hierarchies, and uncertainty about the continuity of tradition and future outcomes" (Grzesiak, s.a.: 1).

11. I extend my sincere acknowledgements to Yelena Tikhomirova for her permission to use her unpublished essay in this paper.

12. Such a technique of narrative split is idiosyncratic for the writer. For instance, all six characters of The waves are traditionally viewed as complementary facets of Woolf's personality.

13. For explaining the workings of the brain Aamodt and Wang used a vivid analogy, comparing the brain with a crowded Chinese restaurant, where everyone is running around, fussing, however eventually things squander out, making a necessary order (2009: 58-59) 
14. It is not accidental that, while describing the neural mechanisms of insight Lehrer illustrates their workings with the excerpt from Woolf's To the lighthouse (2012: 46).

\begin{tabular}{|c|c|}
\hline $\begin{array}{l}\text { Contact data } \\
\text { Olga P. Vorobyova, } \\
\text { Professor, DSc. (Linguistics), } \\
\text { Head of Professor } \\
\text { O.M. Morokhovsky Depart- } \\
\text { ment of English Philology } \\
\text { and Philosophy of Language, } \\
\text { Kyiv National Linguistic } \\
\text { University, } 73 \text { Velyka } \\
\text { Vasyl'kivs'ka St., Kyiv-150, } \\
\text { CPS, 03680, Ukraine; e-mail: } \\
\text { o.p.vorobyova@gmail.com }\end{array}$ & \begin{tabular}{l}
\multicolumn{1}{c}{ Fields of interest } \\
Cognitive poetics, \\
narratology, cognitive \\
studies of Virginia \\
Woolf's short fiction, \\
literary semantics, \\
literary semiotics, \\
stylistics, multimodality \\
studies.
\end{tabular} \\
\hline
\end{tabular}

\section{Résumé in English}

This paper addresses the issue of ambiguity in literary discourse, viewed through its multiple verbal and narrative manifestations in Virginia Woolf's short fiction. The research is aimed at suggesting a set of techniques related to semantic, conceptual, narrative, semiotic, and configurational analyses, brought together to form a flexible algorithm of literary text disambiguation. Regarding ambiguity as a scalar linguistic and literary phenomenon, the processing and interpreting of which is determined by neurobiological properties of human cognition, the paper outlines nine consecutive stages of cognitive poetic interpretation, adapting them for the purpose of discourse disambiguation. The suggested disambiguation design starts with the identification of ambiguity sites as relevant receptive hindrances. It further includes a quadruple of basic conceptual techniques, such as reconstructing key concepts, construing dominant conceptual tropes, tracing discursive dynamics of mental spaces, and building a global conceptual integration network. Along with defining ambiguity-generating instances of literary symbolism, disentangling ambiguity-charged narrative strategies, and conceptualising ambiguity-laden narrative stances grounded in liminality as an inbetween state of mind, the interpretive scheme finalises the analysis with a variety of 
tools used to dismantle heterogeneous layers of literary texture that contain or provoke ambiguities. All these taken together are applied to disambiguate Woolf's A haunted house with its glimmering narrative perspective, protean focalization vantages, shifted narrative foci, and various kinds of verbal ambiguities - cross-referential, referential, predicative, and locative. Tracing the tropology of LIFE / DEATH, SLEEP / AWAKENING, and LOVE, through the dynamics of light that separates or unites people, against the World :: Home / House :: Body triad, the analysis results in the final interpretive insight inscribed in the ambiguous texture of Woolf's short story: love is the light within that transcends death. While outlining the contours of a possible metamethod for literary text disambiguation, based on the integration of traditional and more recent interpretive techniques, the paper highlights some hidden features of the writer's linguistic personality that concern her cognitive style, sensory perception, and emotional priorities.

Key words: ambiguity, conceptual trope, disambiguation, human cognition, interpretive technique, literary discourse, receptive hindrance, short fiction, texture, Virginia Woolf.

\section{Résumé in German}

Der vorliegende Artikel beschäftigt sich mit dem Problem der Disambiguierung im literarischen Diskurs, das an Hand von mehrfachen verbalen Ausdrücken und narrativen Manifestationen in Virginia Woolf's kurzer Prosa studiert wird. Ziel der Studie ist es, eine Reihe von Techniken semantischer, konzeptioneller, narrativer, semiotischer und konfigurationsanalytischer Art anzubieten, um einen flexiblen Algorithmus zur Auflösung sprachlicher Mehrdeutigkeit im literarischen Diskurs zu entwickeln. Basierend auf der Begriffserklärung als skalarem sprachlichem und literarischem Phänomen, dessen Wahrnehmung und Deutung durch neurobiologische Eigenschaften menschlicher Kognition bestimmt werden, beschreibt dieser Beitrag die neun aufeinanderfolgenden Stufen der kognitiven poetologischen Interpretation, die dem Zweck der Disambiguierung des Diskurses angepasst werden. Ausgehend von der 
Feststellung ambiger Stellen als relevanten Schwierigkeiten bei der Interpretation, beinhaltet die vorgeschlagene Gestaltung deren Auflösung die Kombination von vier Grundtechniken der konzeptionellen Analyse, und zwar die Rekonstruktion der wichtigsten Konzepte, das Entwerfen von dominanten konzeptionellen Tropen, das Verfolgen der diskursiven Dynamik von mentalen Räumen und den Aufbau vom globalen Netzwerk konzeptioneller Integration. Dazu gehören auch die Feststellung der generativen Zweideutigkeit literarischer Symbolik, das Entwirren von mehrdeutigen narrativen Strategien und das Verständnis der narrativen mehrdeutigen Positionen basierend auf Liminalität als Zwischenstufe des Bewusstseins. Durch verschiedene Interpretationsverfahren werden heterogene Schichten literarischer Textur analysiert, die Mehrdeutigkeit enthalten und provozieren. All diese Schritte der Analyse werden verwendet, um Woolf's A haunted house mit seiner schimmernden Erzählperspektive, seinen vielfältigen Fokalisierungsvarianten, Verschiebungen von narrativem Fokus und verschiedenen Arten von verbalen Zweideutigkeiten - crossreferentiell, referentiell, prädikativ und lokativ - zu disambiguieren. Im Hintergrund der Triade von Welt :: Haus :: Körper führt das Betrachten der Tropologie von Konzepten LEBEN / TOD, SCHLAF / ERWACHEN und LIEBE durch die Dynamik von Licht, das Menschen trennt oder verbindet, zur endgültigen interpretatorischen Einsicht, die sich in eine gemischte Textur von Virginia Woolf's Erzählung einfügt: Die Liebe ist dieses den Tod überwindende innere Licht. Beim Umreißen der Konturen einer auf der Wechselwirkung von traditionellen und neu entwickelten Techniken der Interpretation basierenden Metamethode zur Auflösung der literarischen Mehrdeutigkeit offenbart der Artikel einige verborgene Merkmale der sprachlichen Identität der Schriftstellerin, die sich auf ihren kognitiven Stil, ihre sinnliche Wahrnehmung und emotionale Prioritäten beziehen.

Stichwörter: Mehrdeutigkeit, konzeptionelle Trope, Disambiguierung, menschliche Kognition, Interpretationstechnik, literarischer Diskurs, Schwierigkeit bei der Wahrnehmung, kurze Prosa, Textur, Virginia Woolf. 


\section{Résumé in French}

L'article proposé s'attache à spécifier le problème de l'ambiguïté dans le discours littéraire, considérée à travers ses multiples manifestations verbales et narratives dans les récits de Virginia Woolf. L'étude vise à présenter toute une série de techniques faisant partie des analyses sémantique, conceptuelle, narrative, sémiotique et configurationnelle afin d'élaborer un algorithme souple permettant la désambiguïsation du discours littéraire. Vu la définition de l'ambiguïté en tant que phénomène linguistique et littéraire scalaire, dont la perception et l'interprétation se déterminent en fonction des capacités neurobiologiques de la cognition humaine, l'article propose neuf étapes consécutives de l'interprétation cognitive poétique, appellées à lever l'ambiguïté du discours. Ayant pour le point de départ l'identification des passages ambigus formant les difficultés de perception pertinentes, le design suggéré de la résolution du problème en question comprend quatre techniques de bases de l'analyse conceptuelle, appliquées à la fois. Il s'agit de reconstruire les concepts clés du texte, de construire ses tropes conceptuels dominants, de tracer la dynamique discursive des espaces mentaux ainsi que d'établir le réseau conceptuel d'intégration. Toutes ces opérations étant accomagnées de la mise en évidence du symbolisme du texte littéraire en tant que source à générer l'équivoque, du démêlage des stratégies narratives servant à créer l'ambigu et de la prise en conscience des positions narratives ambiguës, fondées sur une liminalité en tant qu'état de semi-conscience. La finalité de telle approche est de décortiquer, par le biais de différents procédés de l'interprétation, les couches hétérogènes de la texture qui comprennent ou provoquent les ambiguïtés. Les étapes de l'analyse suggérée sont appliquées pour lever les ambiguïtés dans le récit de Virginia Woolf A haunted house (La maison hantée) qui se caractérise par une perspective narrative scintillante, par un focalisateur qui change de contours de ses positions, par des mutations des focus narratifs de même que par différents types d'ambiguïtés verbales: cross-référentiel, référentiel, prédicatif et locatif. La mise en évidence de la tropologie la VIE / la MORT, le SOMMEIL / le RÉVEIL et l'AMOUR à travers la dynamique de la lumière, qui sépare ou réunit les gens face à la triade l'Univers :: la Maison / le Foyer :: le Corps aboutit à une révélation interprétative finale, inscrite dans 
la texture du récit de Virginia Woolf, qui abonde en ambiguïtés: l'amour est une lumière interne qui vainc la mort. Lors de la présentation de la méthode en question en tant que méta-méthode de la désambiguïsation littéraire qui est fondée sur l'intégration des techniques interprétatives traditionnelles et récentes, l'article se consacre aussi à révéler certaines particularités dissimulées de la personnalité linguistique de l'écrivaine portant sur son style cognitif, sa perception sensorielle ainsi que ses priorités émotionnelles.

Mots-clés: l'ambiguïté, un trope conceptuel, la désambiguïsation, la cognition humaine, une technique interprétative, un discours littéraire, une difficulté de perception, les récits, la texture, Virginia Woolf.

\section{Résumé in Russian}

Статья посвящена проблематике неоднозначности в художественном дискурсе, рассматриваемой сквозь призму её множественных словесных и повествовательных проявлений в малой прозе Вирджинии Вулф. Цель исследования в том, чтобы собрать воедино ряд техник семантического, концептуального, нарративного, семиотического и конфигурационного анализа для выработки гибкого алгоритма снятия неоднозначности художественного дискурса. Исходя из понимания неоднозначности как скалярного языкового и художественного феномена, восприятие и интерпретация которого определяются нейробиологическими свойствами человеческой когниции, в статье очерчиваются девять последовательных этапов когнитивнопоэтологической интерпретации, адаптированных для снятия неоднозначности дискурса. Предлагаемая схема анализа отталкивается от установления мест неоднозначности как релевантных трудностей восприятия. Далее она включает четыре базовые техники концептуального анализа, такие как: реконструкция ключевых концептов, конструирование доминантных концептуальных тропов, раскрытие дискурсивной динамики ментальных пространств и построение глобальной сети концептуальной интеграции. Наряду с установлением художественной символики, порождающей неоднозначности, распутыванием 
неоднозначных повествовательных стратегий и осмысливанием неоднозначных нарративных позиций, основанных на лиминальности как промежуточном состоянии психики, согласно предлагаемой схеме анализ завершается последовательной деконструкцией, c помощью различных приёмов интерпретации, неоднородных слоёв художественной текстуры, содержащих или провоцирующих неоднозначности. Все эти этапы анализа применяются для снятия неоднозначностей в рассказе Вирджинии Вулф "A haunted house" ("Дом с привидениями") c его мерцающей повествовательной перспективой, меняющими контуры позициями фокализатора, сдвигами нарративных фокусов и разнообразными видами словесных неоднозначностей - кроссреференциальных, референциальных, предикативных и локативных. Рассмотрение тропологии концептов ЖИЗНЬ / СМЕРТЬ, СОН / ПРОБУЖДЕНИЕ и ЛЮБОВЬ сквозь призму динамики света, разделяющего или объединяющего людей, на фоне триады Мир :: Дом :: Тело приводит к завершающему интерпретационному прозрению, вписанному в неоднозначную текстуру рассказа Вирджинии Вулф: любовь - это внутренний свет, преодолевающий смерть. Очерчивая контуры возможного метаметода разрешения художественных неоднозначностей, основанного на взаимодействии традиционных и недавно разработанных техник интерпретации, автор статьи выявляет некоторые скрытые черты языковой личности писательницы, касающиеся её когнитивного стиля, чувственного восприятия и эмоциональных приоритетов.

Ключевые слова: неоднозначность, концептуальный троп, снятие неоднозначности, человеческая когниция, техника интерпретации, художественный дискурс, трудность для восприятия, малая проза, текстура, Вирджиния Вулф. 
Article was received by the editorial board 17.05.17;

Reviewed 24.05.17. and 25.05.17.

Similarity Index 11\%. 